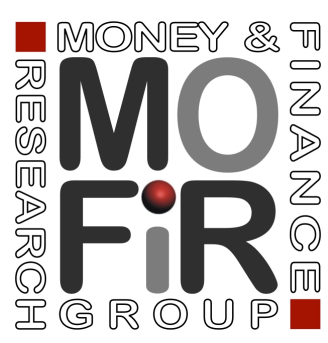

\title{
The Rise of DOMESTIC CAPITAL MARKETS FOR CORPORATE FINANCING: \\ LESSONS FROM EAST ASIA
}

Facundo Abraham Juan J. Cortina

Sergio L. Schmukler

Working paper no. 154

June 2019 


\title{
The Rise of Domestic Capital Markets for Corporate Financing: Lessons from East Asia
}

Facundo Abraham
Juan J. Cortina

June 21, 2019

\begin{abstract}
During the past decades, firms from emerging economies have significantly increased the amount of financing obtained in capital markets. Most of the literature has focused on issuances in international markets, which appear to have been a key driver of the overall activity in a context of financial globalization. This paper explores whether domestic issuances have also played a role in this increase in financing. By examining the case of East Asia, which captures most of the capital raisings among emerging economies, this paper shows that domestic issuances have been the main component of the overall expansion in capital market financing since 2000. As domestic markets developed, more and smaller firms accessed capital markets, while larger corporations increased their funding sources and their resilience to international shocks. The experience of East Asia shows that domestic capital markets can play a useful role and that numerous policies might aid in their development.
\end{abstract}

JEL Classification Codes: F33; G00; G01; G15; G21; G23; G31

Keywords: Asian Financial Crisis; corporate bond markets; corporate financing; Global Financial Crisis; SME capital markets; stock markets; syndicated loan markets

\footnotetext{
* This paper is a joint product of the World Bank Development Research Group, the East Asia and Pacific Region, and the Finance, Competitiveness, and Innovation Global Practice at the Malaysia Knowledge and Research Hub. For helpful comments and data provided, we are grateful to Ashraf Bin Arshad, Irina Astrakhan, Ana Maria Aviles, Anderson Caputo, Jian Chen, Jose de Luna Martinez, Tatiana Didier, Catiana Garcia-Kilroy, Aart Kraay, Norman Loayza, Andrew Mason, Sudhir Shetty, various financial sector experts at the World Bank, and participants at presentations held at the Malaysia Securities Commission and the World Bank (Kuala Lumpur and Washington, DC). We received additional financial support from the World Bank Knowledge for Change Program and Strategic Research Program. Email addresses: fabraham@worldbank.org; jcortinalorente@worldbank.org; sschmukler@worldbank.org.
} 


\section{Introduction}

Firms in emerging economies have significantly increased the amount of financing raised in capital markets. The international issuance activity of these firms has been a key driver of the expansion during the 1990s and 2000s. Financial liberalization in the 1990s allowed emerging economy firms around the world to significantly increase their equity and bond issuances abroad (Henderson et al., 2006; Gozzi et al., 2010; Doidge et al., 2013). More recently, low interest rates in advanced economies after the 2008-09 Global Financial Crisis have led to a boom in international bond issuances by emerging market firms, raising concerns among policy makers about leverage levels and exposure to foreign shocks (Turner 2014; IMF, 2015; McCauley et al., 2015; Bruno and Shin, 2017; Chang et al., 2017; IMF, 2018).

From a theoretical point of view, in a globalized world where financial transactions can take place anywhere, it is initially unclear to what extent emerging market firms would make use of domestic capital markets. Access to international markets allows firms to raise capital and trade in those markets, and domestic investors to buy securities abroad, bypassing domestic markets. As investors and firms prefer to conduct their investing and capital raising activities in the well-established international markets, domestic markets could become irrelevant (Claessens et al., 2002; Levine and Schmukler, 2006). On the other hand, even if barriers to financial transactions are removed, frictions (such as information asymmetries, fixed transactions costs, or tax treatment) can cause market segmentation to persist, preventing some firms and investors to participate in international financial markets (La Porta et al., 1997; Karolyi and Stulz, 2003; Pirinsky and Wang, 2006; Japelli and Pagano, 2008; Bekaert et al., 2011).

In this paper, we use the experience of East Asia to study the performance and role of domestic markets vis-à-vis international ones during the period of increased financial globalization that started in the 1990s. Although our focus is on East Asia, we also examine the equity and bond 
issuance activity of East Asian firms relative to those of other emerging regions. We focus on East Asia for different reasons. First, corporate issuances in East Asia account for most of the capital market activity in emerging economies as a whole. For example, the amount of equity and bonds raised by East Asian firms during the 1990-2016 period accounted for about 70 percent of the total amount raised by firms from emerging regions in domestic and international markets. Second, the East Asia region weighs heavily in international benchmark indexes, which international investors widely use to allocate funds. This interest by international investors might push firms to raise capital in international markets in detriment of domestic markets (Calomiris et al., 2019; The Economist, 2019). Third, following the 1997-98 Asian Financial Crisis, policy makers in the region have made a conscious effort to develop domestic markets as an alternative to international financing. Thus, we can use a time series long enough to study the evolution of these markets as these policies were implemented. In sum, the case of East Asia allows us to examine how international and domestic markets, pushed by different forces, have developed over time and whether they act as substitutes or complements.

To conduct the analysis, we use transaction-level data on equity and corporate bonds issued in domestic and international (cross-border) markets over the period 1990-2016. The data include 124,390 security issuances conducted by 22,945 firms from East Asian economies. The analysis focuses on the largest 10 economies in the region in terms of gross domestic product (GDP). Because East Asian economies are heterogenous, we evaluate the performance of the median economy as well as conduct regressions at the economy-industry-year level. Therefore, we avoid showing only patterns for the largest economies or the most financially developed ones. The data comprise the universe of East Asian issuers: including firms listed in stock exchanges and unlisted firms. The latter account for 60 percent of all bond issuers in East Asia. 
We find that the amount of financing raised in capital markets by East Asian firms has greatly increased since the 1990s, driven by domestic rather than international issuances. The total amount of equity and bond financing raised per year (relative to GDP) in the median East Asian economy doubled between the periods 1990-98 and 2008-16. As a result, the relative size of capital market financing in East Asia has become similar to that in advanced economies. The share of equity raised domestically per year in the median East Asian economy increased from 85 to 97 percent between 1990-99 and 2008-16; that of domestic bonds rose from 36 to 80 percent between the same periods. Because of the high correlation between issuance market and currency denomination, the share of domestic currency bond financing also increased significantly. The larger reliance on domestic markets occurred both at the economy-industry level and within firms. The patterns in East Asia are similar to those in other emerging regions, where domestic equity and bond activity has grown relatively faster than international activity. However, the growth of domestic markets was more subdued in other regions, which still conducted most of their bond issuances abroad during 2008-16.

We explore two dimensions through which domestic capital markets might be complementing international markets for emerging market firms. In particular, we study (i) whether domestic capital markets serve different types of firms (in terms of size) than international markets, and (ii) whether domestic capital markets help diversify financing sources and mitigate shocks in international markets. We find that domestic capital markets feature more and smaller firms than international markets. Consequently, as domestic markets expanded in East Asia, more firms gained access to equity and bond markets, generating growth in the extensive margin. For example, the average number of issuing firms per year in the median East Asian economy more than tripled, from 60 issuers in 1990-98 to 185 issuers in 2008-16. Furthermore, the size of the typical capital market issuer in East Asia declined 38 percent between 1990-98 and 2008-16. The patterns in East Asia stand in contrast to those in other 
regions. In advanced and other emerging economies, the number of issuers has remained fairly constant and the size of the typical issuer has increased over time.

The relatively larger firms with access to international markets have also benefited from the expansion of domestic markets in East Asia. Whereas the relatively smaller issuing firms rely almost exclusively on domestic capital markets, the largest firms raise funds both domestically and abroad. Access to different markets allows firms to mitigate negative shocks in one market by raising more funds in other markets. When international debt markets collapsed during the Global Financial Crisis, firms in East Asia moved from international to domestic bond markets. This "spare tire" function was not present during the Asian Financial Crisis.

The evidence in this paper provides important lessons for policy makers in different regions in the world. Despite the increased financial globalization, domestic capital markets are still important for emerging economies. In East Asia, and as consequence for the group of emerging economies taken as a whole, domestic markets (and not international ones) are the main place where firms go to raise capital market financing. Because these markets serve relatively smaller firms and can cushion shocks, it might be worth trying to develop them. The case of East Asia suggests that, at a minimum, a wide range of policies would be needed to help domestic markets grow. Furthermore, even when domestic markets flourish, it is the large firms that access them. Policy makers in East Asia have tried to address this issue by establishing markets dedicated to small and medium enterprises (SMEs), which have become large by international standards. Although they might be available to other firms and new economic sectors, they tend to serve few firms that, in some cases, are not SMEs but rather larger corporations.

Our paper contributes to three strands of the literature, in addition to the literature on the complementarity between international and domestic capital markets mentioned earlier. First, our paper is consistent with the literature on corporate financing that argues that bond issuance activity 
by emerging economy firms accelerated after the Global Financial Crisis. This literature associates the increasing corporate debt levels in emerging economies post-Global Financial Crisis with a surge in international bond issuances and, potentially, foreign currency risk (Shin, 2013; Chui et al., 2014; Acharya et al., 2015; Caballero et al., 2016). Our paper complements that literature by showing that domestic issuance activity by East Asian firms (the most active users of capital markets among emerging economies) outpaced that in international markets. As a result, most bond issuances during 2008-16, across and within firms, took place in domestic markets. These trends hold for different criteria used in the literature to define international issuances: residence of issuing firms, nationality of issuing firms, and currency denomination. Thus, these findings also show a greater reliance of East Asian firms on domestic currency financing.

Second, our paper adds to the literature that examines how financial development affects firms of different sizes. Research shows that relatively smaller firms benefit more from financial development than larger ones (Guiso et al., 2004; Beck and Dermirguc-Kunt, 2006; Cetorelli and Strahan, 2006; Beck et al., 2008; Ayyagari et al., 2016). The rationale behind this finding is that financial development is typically associated with a reduction in financial frictions (such as high transaction costs, lack of information sharing, or weak enforcement institutions), which are particularly important for small firms. In line with these arguments, our findings are consistent with the fact that more developed domestic capital markets improve access to finance for smaller firms relatively more than for larger corporations.

Third, our paper complements a strand of literature that analyzes aggregate trends in East Asian financial markets. These studies find that financial markets have expanded significantly after both the Asian Financial Crisis and the Global Financial Crisis and have become more diversified, as capital markets have grown faster than the banking sector (Gosh, 2006; Estrada et al., 2010; Park, 2011; Mizen et al., 2012; Cline, 2015; Dekle and Pundit, 2015; Kang et al., 2015; Kowalewski and 
Pisany, 2019). By studying issuance level data, we can examine the type of issuers behind this expansion and how the use of domestic markets has complemented that of international markets.

The remainder of the paper is organized as follows. Section 2 describes the data and methodology. Section 3 documents the growth of domestic and international equity and bond financing by East Asian firms. Section 4 analyzes three aspects of firm financing associated with the growth in capital markets: the extensive margin, issuer size, and financial market diversification. Section 5 concludes and discusses the policy lessons derived from our findings.

\section{Data and Methodology}

\subsection{Data Sources and Sample}

To analyze the issuance activity in East Asia, we use comprehensive, transaction-level data on equity and corporate bonds issued in domestic and international markets over the period 1990-2016. The data come from Thomson Reuters' Security Data Corporation (SDC) Platinum, which provides transaction-level information on new issuances of common and preferred equity, as well as publicly and privately placed bonds. ${ }^{1}$ Because the analysis focuses on corporate financing, we exclude all publicsector issuances, comprising issuances by national, local, and regional governments, government agencies, regional agencies, and multilateral organizations. We also exclude mortgage-backed securities and other asset-backed securities.

In this paper, we cover the 10 largest economies in East Asia (in terms of GDP): China, Hong Kong SAR, Indonesia, Malaysia, the Philippines, the Republic of Korea, Singapore, Taiwan, Thailand, and Vietnam. The data set contains 22,945 unique firms issuing in capital markets and 124,390 security issuances, consisting of 43,196 equity issuances and 81,194 bond issuances over the sample period.

\footnotetext{
1 Thomson Reuters' Security Data Corporation is one of the most widely used databases on transaction-level research. Some prominent studies such as Henderson et al. (2006), Kim and Weisbach (2008), and Bruno and Shin (2017) use the same database. An alternative transaction-level database is Dealogic, which yields similar estimates of issuance activity.
} 
To benchmark against other regions of the world, we also analyze data from other emerging economies (in Eastern Europe and other Asia, Latin America, and the Middle East and Africa) and advanced economies (in North America, Western Europe, and Japan). Appendix Table 1 provides the list of economies included in each group. We focus the analysis on three periods, 1990-98, 1999-2007, and 2008-16. This allows us to compare trends before and after two important milestones: (i) the Asian Financial Crisis (after which East Asian economies implemented efforts to promote domestic markets), and (ii) the Global Financial Crisis (which prompted a boom in international issuances). All values are reported in millions of constant 2011 U.S. dollars.

To account for the fact that our sample of countries is heterogenous, we focus the analysis on the median economy. For the regressions we collapse data at the economy-industry-year level and include economy-industry fixed effects. ${ }^{2}$ In this way, we make sure that we are not simply capturing the trends in the largest economy (China) or in the most financially developed economies in the sample (Hong Kong SAR, Korea, and Singapore). Instead, our results show average trends across equallyweighted East Asian economies. For robustness, we repeated the whole analysis in the paper excluding China, Hong Kong SAR, Korea, and Singapore. ${ }^{3}$ The results are qualitatively similar to the ones reported in the paper.

We classify equity and corporate bond issuances as domestic or international using the residence-based approach followed by the Bank of International Settlements (BIS). We compare the location of the issuance with the residence of the issuing firm (Gruic and Wooldridge, 2012). Domestic securities are, thus, those issued by residents in their local markets. International issuances are those

\footnotetext{
2 This level of aggregation creates an unbalanced panel over 1990-2016. Only economy-industry-year observations with reported issuance activity (of any type) are included in the analysis. We divide industries across nine main categories using the first digit of the Standard Industrial Classification (SIC) codes: agriculture, forestry, and finishing; mining; construction; manufacturing; transportation and utilities; wholesale trade; retail trade; finance, insurance, and real state; and other services.

${ }^{3}$ Data for Korea seem to have poor coverage before 1994 because the reported data on bond issuances increases 57 -fold during 1993-94. Therefore, we also repeated the whole analysis of the paper after excluding all issuance activity from Korea during 1990-93. The results are almost identical.
} 
issued by residents abroad. Using this methodology, the data set includes 38,386 (71,489) equity (bond) issuances in domestic markets and 4,810 (9,703) equity (bond) issuances in international markets.

Besides the residence-based approach, the literature uses two alternative criteria to classify international and domestic corporate bond issuances: the nationality-based and currency-based approaches (Gruić and Wooldridge, 2012; Shin, 2013; Avdjiev et al., 2014; McCauley et al., 2015). The nationality-based approach considers the nationality of a firm instead of its residence. Therefore, issuances by a subsidiary of a foreign-owned firm in the domestic market are considered international, as the parent company resides outside the domestic market. Under the currency-based approach, debt issuances denominated in foreign currency are considered international, and those in local currency as domestic. Because our paper focuses on the role of domestic markets for firms located in East Asia, we use the classification of issuances by the residence approach as our main results. But for robustness we also use the nationality-based and currency-based approaches to estimate the growth of domestic vis-à-vis international bond issuances. The results are robust to using these two alternative measures.

Following the literature, we also repeated the analysis for (i) non-financial sector issuers (residence and currency basis) and (ii) firms whose ultimate parent is a non-financial sector firm (nationality basis). The results for non-financial firms are very similar to the ones reported in the paper. Furthermore, the main results of this paper are robust to excluding firms with some degree of government ownership, which include stated-owned enterprises (SOEs). These firms accounted for 18 percent of the total issuance activity by East Asian firms during the sample period. The results also hold for firms with some degree of government ownership, excluding the rest.

To compare the evolution of capital markets with bank financing, some of the analysis uses syndicated loan data, which also come from SDC. Unlike typical bank loans, transaction-level syndicated loans are available for all economies. Moreover, syndicated loan markets capture a sizable share of bank financing and are the most relevant comparison to capital markets in terms of 
transaction size (amount raised per issuance) and terms of financing such as debt maturity (Ivashina and Scharfstein, 2010; Cerutti et al., 2015). The syndicated loan data include 9,606 issuing firms and 25,493 issuances. To distinguish between domestic and international (cross-border) syndicated loans, we compare the nationality of the lead bank that arranges the deal with the residence of issuing firms. Domestic loans are those in which only domestic banks lead the syndication, whereas international syndicated loans entail the participation of at least one foreign bank acting as a lead arranger.

\subsection{Measure of Firm Size}

To study the types of firms issuing in domestic and international markets over time, we focus on size. We follow the literature that typically uses firm size or collateral to measure financial access across firms or over time (Beck and Dermirguc-Kunt, 2006; Beck et al., 2008; Campello and Larrain, 2016; de la Torre et al., 2017). In addition, we are interested in size because there is evidence that, due to large fixed costs, only large firms have access to international markets (Pagano et al., 2002; Claessens and Schmukler, 2007).

The literature on firms' issuance activity tends to study the size of issuers through balance sheet data, using for example firm assets. ${ }^{4}$ The downside of this approach is that balance sheet data are usually available for firms listed in stock exchanges, but not for unlisted firms that conduct issuances. This issue is not trivial because most corporate debt issuers (about 60 percent) are unlisted (Table 1). We thus use an alternative measure of size that is comparable across firms and covers the whole universe of issuers. We proxy firm size by the average amount raised per issuance, measured over all issuances per firm during the entire 1990-2016 period.

\footnotetext{
${ }^{4}$ See, for example, Pagano et al. (2002), Kim and Segal (2009), Adrian et al. (2013), Didier et al. (2015), Becker and Ivashina (2014), and Bruno and Shin (2017).

5 This statement holds when considering as "listed firms" subsidiaries owned by listed parent companies.
} 
To make sure that the average amount raised is a good proxy for issuer size, we plot the average amount raised and the average assets (also from SDC) for listed firms. The scatter plot shows a high correlation between the two size variables (Appendix Figure 1, Panel A). Regressions of the log of average assets on the log of the average amount raised per issuance yield a point estimate of 0.99 , not statistically different from one but statistically different from zero. To the extent that a similar correlation exists for unlisted firms, the average amount raised should be a good proxy for the analysis of issuer size.

A comparison of the firm size distribution (FSD) of listed and unlisted bond issuers illustrates the importance of using a comprehensive and complete measure of firm size. The FSD of unlisted bond issuers lies to the left of that of listed issuers across the bottom quantiles, indicating that the smallest firms tapping bond markets are unlisted (Appendix Figure 1, Panel B). This confirms that if we were to use assets to measure firm size and only cover listed firms, we would be disregarding the smallest users of bond markets.

To check that our results on firm size are not specific to the proxy we use, we also explored two alternative measures of firm size from Worldscope data for listed firms. In particular, we used total assets and net sales, taking the values reported by firms in their end-of-year balance sheets. Both sets of results with the alternative measures are qualitatively and quantitatively similar to the ones reported in the paper. That is, the size of listed firms issuing in capital markets, in terms of assets and sales, follows the same trend as the size of firms based on issuance volume.

\section{Capital Market Financing}

\subsection{The Rise of Equity and Bond Financing}

Since the early 1990s, firms in East Asia have significantly increased the amount of funds raised in capital markets. In the median East Asian economy, the average amount of capital raised per year 
through equity and bonds increased by factors of 2 and 5, respectively, between the periods 1990-98 and 2008-16.

Although East Asian economies grew fast over the sample period, capital market financing increased even faster, especially in bond markets. The amount raised in equity per year increased from 1.3 percent to 1.6 percent of GDP between the periods 1990-98 and 2008-16 (Figure 1, Panel A). The annual amount raised in equity to GDP in East Asia was the highest among advanced and emerging regions for every period in our sample. The amount raised through bond issuances has grown significantly faster. The total amount raised in bonds per year increased from 1.6 percent to 4.5 percent of GDP between 1990-98 and 2008-16. In other words, bond financing was about three times equity financing in 2008-16, whereas in 1990-98 both values were roughly the same. The ratio of the amount raised in bonds to GDP is also significantly larger than in other emerging economies. However, the value still lags that in advanced economies. The patterns in capital market financing in East Asia contrast with those in syndicated loan financing, where the annual amount raised as a ratio to GDP has fallen over time. ${ }^{6}$

The expansion of capital market activity by East Asian firms is also evident when analyzing the more widely used indicator of market capitalization (Figure 1, Panel B). Stock and corporate bond market capitalization (as a ratio of GDP) have significantly expanded in the region since the 1990s and, as a result, amounts outstanding have become similar to those in advanced economies. In addition, East Asian corporate capital markets have grown relatively faster than corporate bank credit, suggesting a trend toward more diversified financing sources. Note, however, that market capitalization can be driven not only by growth in issuances but also by revaluation of asset prices.

\footnotetext{
${ }^{6}$ Although there is considerable heterogeneity in the levels of issuance activity across economies in East Asia, the reported trends tend to hold across them (Appendix Figure 2).
} 


\subsection{Domestic vs. International Markets}

To formally assess the growth in equity and bond issuance activity in East Asia and examine to what extent domestic and international issuances have driven this growth, we estimate panel ordinary least squares (OLS) regressions of the log (1+the annual amount raised) by each industry in each East Asian economy during 1990-2016 on dummy variables for the periods 1999-2007 and 2008-16. ${ }^{7}$ We use the period 1990-98 as the base, so we omit the dummy for these years. The regressions include economyindustry fixed effects to control for differences across economies and industries that are constant over time. We cluster standard errors at the economy-industry level, as we do for other regressions in the paper. We estimate separate models for total, domestic, and international issuances.

The estimated coefficients imply that the total amount raised in equity and bonds by East Asian firms at the economy-industry level has increased over time (Table 2, Panel A). In the period 2008-16, the annual amount raised per economy-industry in equity and bonds was about 180 percent and 277 percent higher than in 1990-98, respectively. The expansion of domestic issuance activity has been the main driver of this growth. Between the periods 1990-98 and 2008-16, the annual amount raised domestically per economy-industry increased 187 percent in equity and 381 percent in bonds. International issuances have also grown during the last sample period, which is consistent with the literature, but this growth was much slower than the growth of domestic issuances. The annual amount raised per economy-industry in international equity and bond markets increased 73 percent and 58 percent, respectively, between 1990-98 and 2008-16.

For corporate bonds, we repeat the analysis using the two alternative definitions of international bond issuances described in the data section: by nationality of issuers and by currency denomination (Table 2, Panel B). The estimates are fairly robust. The alternative estimates show that domestic issuances have been the main driver of the growth in corporate bond raising activity. Our

\footnotetext{
7 The dummies take value one for each year in the corresponding period and zero otherwise.
} 
results also indicate that the reliance on domestic currency bond financing by East Asian firms at the economy-industry level has increased significantly over time.

As the amount issued in domestic markets grew faster than the amount issued internationally, the share of capital market financing obtained domestically increased (Figure 2). In particular, the share of equity raised domestically per year by the median East Asian economy increased from 85 percent of the total during 1990-98 to 97 percent during 2008-16. In bond markets, international issuances dominated during the pre-crisis period. However, this trend reversed in the 2000 s and bond raising activity by East Asian firms now takes place predominantly in domestic markets. The share of bond financing raised in domestic markets was 36 percent in 1990-98, 65 percent in 1999-07, and 80 percent in $2008-16^{8}$

The patterns of equity financing in East Asia are similar to those in other regions, where equity is also predominantly raised in domestic markets and the share of domestic equity financing has increased over time. The evidence also suggests that domestic bond activity has grown relatively faster than the international activity in other emerging economies. However, in contrast to East Asia, other regions still conducted most of their bond issuances in international markets during 2008-16.

To formally show the shift in the composition from international to domestic markets in East Asia at the economy-industry level, we estimate panel OLS regressions of the share of the total amount raised in domestic markets per economy, industry, and year during 1990-2016 on dummy variables for the periods 1999-2007 and 2008-2016 (Table 3, Panel A). We analyze separately equity and bonds, including economy-industry fixed effects. In the period 1990-98, the average share of equity and bonds raised per year in domestic markets across economy-industries was 72 percent and 21 percent, respectively. The estimates for equity issuances imply that this share experienced no growth in 1999-

\footnotetext{
${ }^{8}$ The trend of a growing share of equity and bonds raised in domestic markets tends to hold for every East Asian economy (Appendix Figure 3).
} 
2007; but it increased to 91 percent in 2008-16. For bond issuances, the share of domestic issuances increased to 49 percent in 1999-2007 and to 69 percent in 2008-16.

We then examine whether the switch toward domestic capital markets not only occurred within industries but also within firms (Table 3, Panel B). Namely, we estimate panel regressions of the share of the total raised in domestic markets per firm and year during 1990-2016 on dummy variables for the periods 1999-2007 and 2008-2016. We estimate separate models for equity and bonds, including firm fixed effects. In this way, we focus on within firm changes over time, disregarding the compositional changes in the set of firms raising new capital, that is, different firms issuing in different markets at different points in time.

A relevant issue when running regressions at the firm level is that the number of issuers varies significantly across economies. For example, China and Korea accounted for 75 percent of the total number of East Asian issuers during 2008-16. Thus, the estimation results could be driven by the trends in those economies with relatively more issuers. We address this issue by estimating weighted least squares (WLS) regressions. In particular, we assign each firm-year observation a weight equal to $1 / N_{i t}$, with $N_{i t}$ being the total number of issuers per economy-industry $i$ and period $t(1990-98,1999$ 2007, and 2008-16). The sum of the weights of all observations per economy, industry, and period equals one, which means that every economy-industry has the same weight in the regressions. Using this method, economies with relatively more issuers do not have relatively more weight and, instead, our results show average trends across equally-weighted East Asian economies.

The regression results imply that part of the overall switch toward domestic markets occurred within firms (Table 3, Panel B). The average share of equity issued domestically (rather than internationally) per firm slightly increased over time, although it was already high in 1990-98. In that period, this share was 89 percent and increased to 92 percent in 2008-16. In contrast, the average fraction of bonds issued domestically per firm greatly increased over time. This share increased by 28 
percentage points, from 39 percent in 1990-98 to 67 percent in 2008-16. For robustness, we also run non-weighted OLS regressions. Although these regressions yield similar results to the ones reported, the coefficient estimates are slightly smaller (Appendix Table 2). This means that the within-firm switch from international to domestic markets was less prominent in relatively larger economies, such as China and Korea.

\section{Firms Using Capital Markets}

Next, we examine three aspects through which the expansion of domestic capital markets might have impacted firm financing: the extensive margin, issuer size, and financial market diversification.

\subsection{Extensive Margin}

The growth in the amount raised in East Asian capital markets has been accompanied by an expansion in the extensive margin. In other words, an increasing number of firms have been using capital markets to obtain financing over the years. In the median East Asian economy, the average number of yearly issuers per period has more than tripled from 60 to 185 issuers between 1990-98 and 2008-16 (Figure 3, Panel A). This overall pattern holds for equity and bond markets, and contrasts with that in other emerging and advanced economies, where the level of yearly issuers and its growth over time were significantly lower.

A broader use of domestic rather than international markets seems to be behind the overall increase in the number of issuing firms in East Asia. Whereas the number of international issuers did not increase much over time, the number of domestic issuers has substantially expanded (Figure 3, Panel B). The number of issuers per year in domestic equity and bond markets increased almost threefold and six-fold, respectively, between 1990-98 and 2008-16. The number of international issuers per year increased for equity (though the level is still relatively small) and declined for bonds. 
Regressions at the economy-industry level provide robust evidence of the reported growth in the extensive margin. We estimate panel OLS regressions of the log (1+the number of issuers) per economy, industry, and year during 1990-2016 on dummy variables for the periods 1999-2007 and 2008-16, in addition to economy-industry fixed effects. The estimates imply that, on average, the number of yearly issuers expanded considerably within industries. In particular, the number of equity and corporate bond issuers per year more than doubled between 1990-98 and 2008-16 (Table 4). For equity, the number of domestic and international issuers increased over time, with the former growing significantly faster. Regarding bonds, only domestic markets show a statistically significant growth in the number of yearly issuers, fully driving the aggregate patterns within this instrument. ${ }^{9}$

\subsection{Issuer Size}

As the extensive margin expanded over time, smaller firms have accessed capital markets to raise funds (Figure 4). The size of the median issuer in the median East Asian economy has consistently declined over time within equity and corporate bond markets. Specifically, the size of the typical equity and bond issuer declined by 60 percent and 30 percent, respectively, between 1990-98 and 2008-16. This pattern contrasts with other emerging and advanced economies, where the median issuer size has tended to increase over time.

Because domestic markets attract relatively smaller firms than international markets, the fall in the size of issuers could be a consequence of the broader use of domestic markets. In particular, firms issuing domestic equity and bonds are about 30 percent the size of those issuing international securities (Figure 5). ${ }^{10}$ Thus, the FSD of domestic issuers is more left skewed than that of international issuers.

\footnotetext{
${ }_{9}$ Although not reported, the intensive margin (changes in the amount raised within firms) yields a more nuanced picture. For equity, we do not find a change in the amount raised per firm, either domestically or internationally. For bonds, the amount raised per firm increased over time in both domestic and international markets.

${ }^{10}$ We define domestic issuers as firms that issue equity or debt in domestic markets only. International issuers are firms that issue capital in international markets at least once over the sample period.
} 
To formally assess the changes in issuer size over time, we estimate panel OLS regressions of the size of equity and corporate bond issuers in East Asia during 1990-2016 on dummy variables for the periods 1999-2007 and 2008-16. These regressions also include economy-industry fixed effects. The dependent variable is the log of size of the median issuer per economy, industry, and year. Therefore, we make sure that each economy-industry-year observation has the same weight in the regression and that industries in countries with more issuing firms do not drive the results.

The estimates show that the median size of issuing firms declined in equity and bond markets relative to the 1990-98 period (Table 5). Mirroring the overall statistics presented above, the size of the typical issuer per economy-industry declined by around 59 percent in equity markets and by 33 percent in bond markets between 1990-98 and 2008-16. For bonds, the use of domestic markets is clearly driving this pattern: the size of domestic issuers has fallen over time whereas the size of international issuers, if anything, has increased. In the case of equity, the issuer size declined for both domestic and international issuers. However, it is important to consider that international equity issuers account for a very small fraction of the total number of equity issuers. In the last period of our sample (2008-16), firms issuing international equity accounted for about 9 percent of the total equity issuers in the median East Asian economy. Thus, changes in the size of domestic issuers are most likely driving the trends in equity markets. For robustness, we run regressions using total assets of listed firms (instead of our proxy based on issuance size), which show an even larger decline in the size of equity and bond issuers between 1990-98 and 2008-16 (Appendix Table 3).

\subsection{Financial Market Diversification}

So far, the analysis has shown how an increasing number of relatively smaller firms seem to have benefited from the development of domestic capital markets in East Asia. But we are also interested in determining whether the larger corporations already using capital markets have benefited from this 
development as well. On the one hand, these firms have access to international markets and might not rely much on domestic capital markets. On the other hand, even if these firms use international markets, they might still use domestic capital markets to diversify their sources of financing and mitigate shocks in other markets.

To better understand the role of domestic capital markets in East Asia, we study how these markets are used vis-à-vis other markets across two different dimensions: (i) the cross-sectional size distribution of issuers and (ii) during normal vs. crisis periods. To do this, we compare the funding in capital markets with that in syndicated loans markets. These types of loans pool funds from several banks to lend large amounts of credit and are the main alternative to corporate bond financing in terms of issuance size and debt maturity. With syndicated loans included into the sample, we have six different markets that can be simultaneously analyzed: domestic equity, international equity, domestic bonds, international bonds, domestic syndicated loans, and international syndicated loans.

Market access varies significantly across firm size. Whereas the relatively smaller issuers depend almost entirely on domestic equity and bond markets, larger firms tend to use a wider set of instruments, issued in different locations. We classify issuers into ten deciles by firm size and examine the share of firms, per decile, issuing in different markets (Figure 6). In the first decile (the smallest issuers), 97 percent of the firms are domestic equity and/or domestic bond issuers, whereas only 7 percent of those firms issue in other markets. Relatively larger firms also use domestic capital markets, but they seem to raise capital across markets in a more balanced manner. For instance, 46 percent of firms in the tenth decile (the largest firms) use domestic capital markets, 21 percent use domestic syndicated loans, 7 percent use international equity, 17 percent use international bonds, and 34 percent use international syndicated loans. The fact that the sum of different types issuers is close to 100 percent in the first decile means that most of the smallest issuing firms stick to only one (domestic) 
market. ${ }^{11}$ Because smaller firms are typically younger, this pattern of financing across firm size is consistent with a pecking order that suggests that firms use domestic markets first and, then, access international and syndicated loan markets at a later stage, when they become larger. ${ }^{12}$

Access to various markets can be beneficial because, when the supply of funds from specific markets declines, firms can compensate by raising more funds in less affected markets. Adrian et al. (2013) and Becker and Ivashina (2014) provide evidence that firms in the United States switch from syndicated loan to bond markets to withstand credit supply shocks on the banking sector. Taking a more global perspective, Cortina et al. (2019) show how firms also switch between international and domestic debt markets during periods of financial crises. This behavior is consistent with the view that capital markets can act as a spare tire, providing financing when the banking sector is in crisis (Greenspan, 1999; Levine et al., 2016).

Following this research, we study changes in debt issuance composition across markets for East Asian firms around the Asian Financial Crisis and the Global Financial Crisis. The spare tire function of alternative debt markets was not observed during the Asian Financial Crisis, perhaps because domestic capital markets were not as developed then (Figure 7, Panel A). However, the expansion of domestic markets over time seems to have allowed firms to move across different markets during the Global Financial Crisis. As the crisis hit syndicated loan and international bond markets, East Asian firms turned to domestic bond markets (Figure 7, Panel B). While the number of total syndicated loan and international bond issuances declined by 20 percent and 30 percent, respectively, during 2008-09, domestic corporate bond issuances expanded by 110 percent. Because of this movement toward domestic bond markets, the total number of debt issuances (bonds plus

\footnotetext{
11 The sum of these percentages does not need to be 100 percent because some firms in each decile can issue in more than one market at the same time and thus belong to more than one group of issuers.

12 There is a very high correlation between firm size (in terms of assets) and age. Using the Worldscope data on listed East Asian firms, a 1 percent increase in age is associated with a 0.5 percent increase in size.
} 
syndicated loans) did not decline. The movement toward domestic bond markets is even larger when focusing only on those firms issuing debt in international markets before the crisis (Figure 7, Panel C). ${ }^{13}$ These firms increased their domestic bond issuances by 150 percent, while declining issuances in all the other markets. That is, international debt issuers, which are the relatively larger corporations, shifted toward domestic bond markets during the Global Financial Crisis.

\section{Conclusions and Policy Lessons}

Since the 1990s, East Asian firms have increased their issuance activity in capital markets, most notably, in domestic markets during the 2000s. As the amount raised domestically grew faster than the amount raised internationally, domestic markets have become the predominant place where equity and bonds are issued, and local currencies the predominant denomination of bond contracts. In addition, the number of East Asian firms issuing in domestic markets has significantly increased over time, whereas the number of international issuers has remained stagnant.

Domestic markets are not only very active, but they seem to provide several and sometimes complementary benefits relative to international markets. Domestic markets attract relatively smaller firms than international markets. In addition, large corporations seem to use domestic markets to diversify financing sources and mitigate shocks in international markets. Furthermore, because of the high correlation between the currency denomination of bonds and the market of issuance, domestic markets seem to facilitate domestic currency financing. Despite these advantages, the expanded use of domestic markets has not come without risks. The boom in corporate bond financing over the last decade has increased corporate leverage, leading to higher credit risk (Chan et al., 2018). This credit growth has also raised concerns related to declines in lending standards and further risk taking (IMF, 2018; McKinsey, 2018).

${ }^{13}$ To compute this panel, we only keep firms that issued international debt at least once before 2008. 
Our evidence provides important policy lessons. First, to have a more comprehensive understanding of the trends in capital market financing by emerging market firms, domestic markets cannot be overlooked. Whereas international capital markets have indeed been an important contributor to the corporate finance boom that started in the $1990 \mathrm{~s}$, domestic markets have played an even more important role since the new millennium. Thus, focusing only on the amount of foreign currency debt issued abroad misses a significant part of the composition of corporate liabilities. Bringing domestic issuances into the analysis will help measure more adequately the corporate exposure to different shocks. Although our evidence focuses on East Asia, the activity in this region is large and drives the overall financing conducted by emerging economies.

Second, whereas the experience of East Asia shows that domestic capital markets can play an important role in emerging economies, our data also suggest that outside East Asia the relative importance of domestic capital markets (in particular bond markets) is much lower. In other words, East Asia seems to be an exception rather than the rule in the emerging world. In part, the uniqueness of East Asia can be traced back to the Asian Financial Crisis, after which policy makers implemented a series of capital market reforms with the goal of diversifying financial markets and reducing the dependence on bank lending, which was perceived to be an important factor leading to the crisis (Kawai 1998; Corsetti et al., 1999; Radelet and Sachs, 2000; Geithner, 2007; Park et al., 2017). Whether a similar experience can be replicated elsewhere is unclear, but at least East Asia might serve as a role model for other regions to follow.

To get a sense of the numerous and different types of capital market reforms implemented in East Asia, we were able to obtain information on the policies issued by authorities in Indonesia, Korea, Malaysia, the Philippines, and Vietnam. Overall, we observe 68 capital market reforms which we classify into three categories based on their goal: (i) expansion of the investors base (e.g., allowing the entry of foreign investors or creating new types of investors, such as pension or mutual funds), (ii) 
improvement of market infrastructure (e.g., introducing new instruments or launching new exchanges), and (iii) enhancement of investors protection (e.g., enacting new regulations or improving corporate governance practices) (Appendix Figure 4). ${ }^{14}$

Identifying whether specific policy reforms helped jump start domestic markets is not an easy task. Reforms were not concentrated in a specific period, but instead were implemented throughout an extended time following the Asian Financial Crisis. In addition, the different categories of reforms were not adopted in a sequential manner. In other words, economies did not follow a path in which they put in place reforms of a certain type first and then moved on to other types of reforms. It might be the case that no single reform was more relevant than others. Instead, the whole reform process might have acted as a signal to the market that policy makers were committed to developing domestic capital markets and might have provided the different rules and regulations that markets needed to flourish. These changes, in turn, could have encouraged more firms and investors to use these markets.

There are other additional factors that could explain why East Asia is different from other emerging regions. Strong fiscal positions that reduce "crowding out" by the public sector could have allowed more capital market financing to be channeled to the corporate sector. It might have also been the case that high savings in the region and the establishment of domestic institutional investors increased the availability of funds in domestic markets. Thus, a deeper understanding of the factors behind the development of capital markets in East Asia is needed.

Third, although the development of domestic markets has allowed relatively smaller firms to raise funds in capital markets, SMEs do not seem to access them. According to the size of issuances as well as assets of listed firms, issuing firms in East Asia appear to be relatively large. Concerned by this pattern, policy makers in the region have complemented the above-mentioned policies by trying to develop alternative capital markets targeted specifically at SMEs. As a consequence, SME markets

\footnotetext{
${ }^{14}$ The complete list of compiled reforms in each economy can be found in Appendix Tables 4 to 8.
} 
have become large in East Asia when compared to those in other regions, including advanced ones. However, preliminary evidence suggests that few firms are participating in these SME markets, relative to the number of issuers in traditional markets and the total universe of SMEs. In addition, whereas in some cases these markets are effectively serving SMEs, in others they are serving rather large corporations. On the positive side, these markets seem to be providing financing to new sectors that are not adequately served by traditional markets. ${ }^{15}$

Even if only large firms use domestic capital markets, their actions can produce positive spillovers for smaller firms. For example, as more firms turn to capital markets for funds, the demand for bank financing from these firms might drop, freeing funds that can be channeled toward other (arguably smaller) corporations. Moreover, there is evidence that firms issuing in capital markets can act as financial intermediaries, raising funds at low interest rates in these markets and then on-lending the proceeds at higher rates, perhaps "crowding in" smaller firms (Caballero et al., 2016; Bruno and Shin, 2017). It would be useful to understand to what extent these spillovers to non-issuers and smaller firms are present. To the extent that direct access to markets is beneficial, it would be interesting to examine whether alternative instruments, such as securitization or mini-bonds, might be more effective at promoting the participation of SMEs in capital markets.

\footnotetext{
${ }^{15}$ Appendix Table 9 and Appendix Figure 5 show evidence on firms issuing in SME capital markets in China (SME Board, ChiNext, and NEEQ), Hong Kong SAR (GEM), and Taiwan (TPEx).
} 


\section{References}

Acharya, V., S. G. Cecchetti, J. De Gregorio, S. Kalemli-Özcan, P. R. Lane, and U. Panizza. 2015. Corporate Debt in Emerging Economies: A Threat to Financial Stability? Brookings Institution.

Adrian, T., P. Colla, and H. S. Shin. 2013. "Which Financial Frictions? Parsing Evidence from the Financial Crisis of 2007-09.” NBER Macroeconomics Annual, 27 (1): 159-214.

Avdjiev, S., M. Chui, and H. S. Shin. 2014. "Non-financial Corporations from Emerging Market Economies and Capital Flows." BIS Quarterly Review, December, Bank for International Settlements.

Ayyagari, M., P. F. Juarros, M. S. Martinez Peria, and S. Singh. 2016. "Access to Finance and Job Growth: Firm-level Evidence across Developing Countries.” Policy Research Working Paper 7604, World Bank.

Bekaert, G., C. R. Harvey, C. T. Lundblad, and S. Siegel. 2011. "What Segments Equity Markets?" Review of Financial Studies, 24 (12): 3842-90.

Beck T., and A. Demirguc-Kunt. 2006. "Small and Medium-size Enterprises: Access to Finance as a Growth Constraint.” Journal of Banking and Finance, 30 (11): 2931-43.

Beck T., A. Demirguc-Kunt, L. Laeven, and R. Levine. 2008. "Finance, Firm Size, and Growth." Journal of Money, Credit and Banking, 40 (7): 1379-1405.

Becker, B., and V. Ivashina. 2014. "Cyclicality of Credit Supply: Firm-level Evidence." Journal of Monetary Economics, 62 (C): 76-93.

Bruno, V., and H. S. Shin. 2017. "Global Dollar Credit and Carry Trades: A Firm-level Analysis." Review of Financial Studies, 30 (3): 703-49.

Caballero, J., U. Panizza, and A. Powell. 2016. “The Second Wave of Global Liquidity: Why Are Firms Acting Like Financial Intermediaries?" IDB Working Paper 641, Inter-American Development Bank.

Calomiris, C., M. Larraín, S. Schmukler, and T. Williams. 2019. "Search for Yield in Large International Corporate Bonds: Investor Behavior and Firm Responses.” NBER Working Paper 25979 and World Bank Policy Research Working Paper 8890, National Bureau of Economic Research and World Bank.

Campello M., and M. Larrain. 2016. "Enlarging the Contracting Space: Collateral Menus, Access to Credit, and Economic Activity." Review of Financial Studies, 29 (2): 349-83.

Cerutti, E., G. Hale, and C. Minoiu. 2015. "Financial Crises and the Composition of Cross-Border Lending." Journal of International Money and Finance, 52 (C): 60-81.

Cetorelli, N., and P. E. Strahan. 2006. "Finance as a Barrier to Entry: Bank Competition and Industry Structure in Local U.S. Markets." Journal of Finance, 61 (1): 437-61.

Chan, W., O. Dodd, and M. Kilimipalli. 2018. "Evaluating the Impact of Post-crisis Growth in Emerging Market Corporate Debt.” Working Paper.

Chang, R., A. Fernandez, and A. Gulan. 2017. "Bond Finance, Bank Credit, and Aggregate Fluctuations in an Open Economy.” Journal of Monetary Economics, 85 (C): 90-109. 
Chui, M., I. Fender, and V. Sushko. 2014. "Risks Related to EME Corporate Balance Sheets: The Role of Leverage and Currency Mismatch.” BIS Quarterly Review, September, Bank for International Settlements.

Claessens, S., D. Klingebiel, and S. L. Schmukler. 2002. "The Future of Stock Exchanges in Emerging Economies: Evolution and Prospects." In R. E. Litan and R. Herring (eds.), BrookingsWharton Papers on Financial Services, 167-202, Brookings Institution.

Claessens, S., and S. L. Schmukler. 2007. "International Financial Integration through Equity Markets: Which Firms from Which Countries Go Global?” Journal of International Money and Finance, 26 (5): 788-813.

Cline, W. R. 2015. “The Financial Sector and Growth in Emerging Asian Economies.” Working Paper Series WP15-5, Peterson Institute for International Economics.

Corsetti, G., P. Pesenti, and N. Roubini. 1999. "What Caused the Asian Currency and Financial Crisis?" Japan and the World Economy, 11 (3): 305-73.

Cortina, J. J., T. Didier, and S. L. Schmukler. 2019. "Global Corporate Borrowing during Crises: The Effects of Switching across Markets.” Mimeo. Previous version available as CEPR Discussion Paper DP13008.

Dekle, R., and M. Pundit. 2015. “The Recent Convergence of Financial Development in Asia.” ADB Economics Working Paper Series 440, Asian Development Bank.

de la Torre, A., Gozzi, J. C., and S. L. Schmukler. 2017. Innovative Experiences in Access to Finance: Market Friendly Roles for the Visible Hand? Latin American Development Forum, World Bank.

Didier, T., R. Levine, and S. L. Schmukler. 2015. "Capital Market Financing, Firm Growth, and Firm Size Distribution.” Policy Research Working Paper 7353, World Bank.

Doidge, C., G. A. Karolyi, and R. M. Stulz. 2013. "The U.S. Left Behind? Financial Globalization and the Rise of IPOs Outside the U.S.” Journal of Financial Economics, 110 (30): 546-73.

Economist, The. 2019. "Economies and Stockmarkets Do Not Always Match Up Well.” May 25.

Estrada, G., D. Park, and A. Ramayandi. 2010. "Financial Development and Economic Growth in Developing Asia.” ADB Economics Working Paper Series 233, Asian Development Bank.

Geithner, T. 2007. "Reflections on the Asian Financial Crisis." Speech at the Trends in Asian Financial Sectors Conference, June, Federal Reserve Bank of San Francisco.

Gosh, S. R. 2006. East Asian Finance: The Road to Robust Markets. World Bank.

Gozzi, J. C., R. Levine, and S. L. Schmukler. 2010. “Patterns of International Capital Raisings.” Journal of International Economics, 8 (1): 45-57.

Greenspan, A. 1999. "Do Efficient Financial Markets Mitigate Financial Crises?” Financial Markets Conference of the Federal Reserve Bank of Atlanta, October.

Gruić, B., and P. Wooldridge. 2012. "Enhancements to the BIS Debt Securities Statistics." BIS Quarterly Review, December, Bank of International Settlements.

Guiso, L., P. Sapienza, and L. Zingales. 2004. “Does Local Financial Development Matter?” Quarterly Journal of Economics, 119 (3): 929-69. 
Henderson, B. J., N. Jegadeesh, and M. S. Weisbach. 2006. "World Markets for Raising New Capital." Journal of Financial Economics, 82 (1): 63-101.

IMF. 2015. "Corporate Leverage in Emerging Markets - A Concern?” In IMF Global Financial Stability Report October 2015 - Vulnerabilities, Legacies, and Policy Challenges: Risks Rotating to Emerging Markets, 83-114, International Monetary Fund.

IMF. 2018. “The Riskiness of Credit Allocation: A Source of Financial Vulnerability?” In IMF Global Financial Stability Report April 2018 - A Bumpy Road Ahead? 57-92, International Monetary Fund.

Ivashina, V., and D. Scharfstein. 2010. "Bank Lending during the Financial Crisis of 2008." Journal of Financial Economics, 97 (1): 319-38.

Japelli, T., and M. Pagano. 2008. "Financial Market Integration under EMU." European Economy Economic Papers 312, European Commission.

Kang, H., P. Jeasakul, and C. H. Lim. 2015. “A Bird's-Eye View of Finance in Asia.” In R. Sahay, J. Schiff, C. H. Lim, C. Sumi, and J. Walsh (eds.), The Future of Asian Finance, 9-37, International Monetary Fund.

Karolyi, G. A., and R. M. Stulz. 2003. “Are Financial Assets Priced Locally or Globally?” In G. M. Constantinides, M. Harris, and R. M. Stulz (eds.), Handbook of the Economics of Finance, 975-1020, Elsevier.

Kawai, M. 1998. "The East Asian Currency: Causes and Lessons." Contemporary Economic Policy, 16 (2): $157-72$.

Kim, W., and M. Weisbach. 2008. "Motivations for Public Equity Offers: An International Perspective." Journal of Financial Economics, 87 (2): 281-307.

King, M., and D. Segal. 2009. "The Long-Term Effects of Cross-Listing, Investor Recognition, and Ownership Structure on Valuation.” Review of Financial Studies, 22 (6): 2393-421.

Kowalewski, O., and P. Pisany. 2019. "What Drove the Growth of the Corporate Bond Markets in Asia?" Research in International Business and Finance, 48 (C): 365-80.

La Porta, R., F. Lopez-De-Silanes, A. Shleifer, A., and R. W. Vishny. 1997. "Legal Determinants of External Finance." Journal of Finance, 52(3): 1131-50.

Levine, R., C. Lin, and W. Xie. 2016. "Spare Tire? Stock Markets, Banking Crises, and Economic Recoveries.” Journal of Financial Economics, 120 (1): 81-101.

Levine, R., and S. L. Schmukler. 2006. "Internationalization and Stock Market Liquidity." Review of Finance, 10 (1): 153-87.

McCauley, R., P. McGuire, and V. Sushko. 2015. "Global Dollar Credit: Links to US Monetary Policy and Leverage.” Economic Policy, 30 (82): 187-229.

McKinsey. 2018. “Rising Corporate Debt. Peril or Promise?” Discussion Paper. McKinsey Global Institute.

Mizen, P., F. Packer, E. Remolona, and S. Tsoukas. 2012. "Why Do Firms Issue Abroad? Lessons from Onshore and Offshore Corporate Bond Finance in Asian Emerging Markets.” Working Paper 401, Bank for International Settlements. 
Pagano, M., A. A. Röell, and J. Zechner. 2002. "The Geography of Equity Listing: Why Do Companies List Abroad?” Journal of Finance, 57 (6): 2651-94.

Park, C. Y. 2011. “Asian Financial System: Development and Challenges.” ADB Economics Working Paper Series 285, Asian Development Bank.

Park, C. Y., J. Lee, J. Villafuerte, and P. Rosenkranz. 2017. "20 Years After the Asian Financial Crisis: Lessons Learned and Future Challenges.” ADB Briefs 85, Asian Development Bank.

Pirinsky, C., and Q. Wang. 2006. “Does Corporate Headquarters Location Matter for Stock Returns?” Journal of Finance, 61 (4): 1991-2015.

Radelet, S., and J. Sachs. 2000. "The Onset of the East Asian Financial Crisis.” In P. Krugman (ed.), Currency Crises, 105-153, University of Chicago Press.

Shin, H. S. 2013. "The Second Phase of Global Liquidity and its Impact on Emerging Economies." Proceedings, issue November, 1-10, Federal Reserve Bank of San Francisco.

Turner, P. 2014. "The Global Long-Term Interest Rate, Financial Risks and Policy Choices in EMEs." BIS Working Papers 441, Bank for International Settlements. 
Figure 1. Growth in Equity and Corporate Bond Financing

This figure shows the evolution of capital markets and banks over 1990-2016. Panel A shows, for the median economy in each region and period, the amount of equity, corporate bonds, and syndicated loans raised per year as a percentage of GDP. Panel B shows, for the median economy in each region and period, the average size of financial markets as a percentage of GDP. In Panel B, "equity" refers to stock market capitalization, "corporate bonds" to the amount outstanding of domestic private bonds, and "banks" to the amount oustanding of private credit granted by domestic banks. The market capitalization data come from the World Bank Financial Development and Structure Dataset (version June 2017).

\section{A. Total Amount Raised}

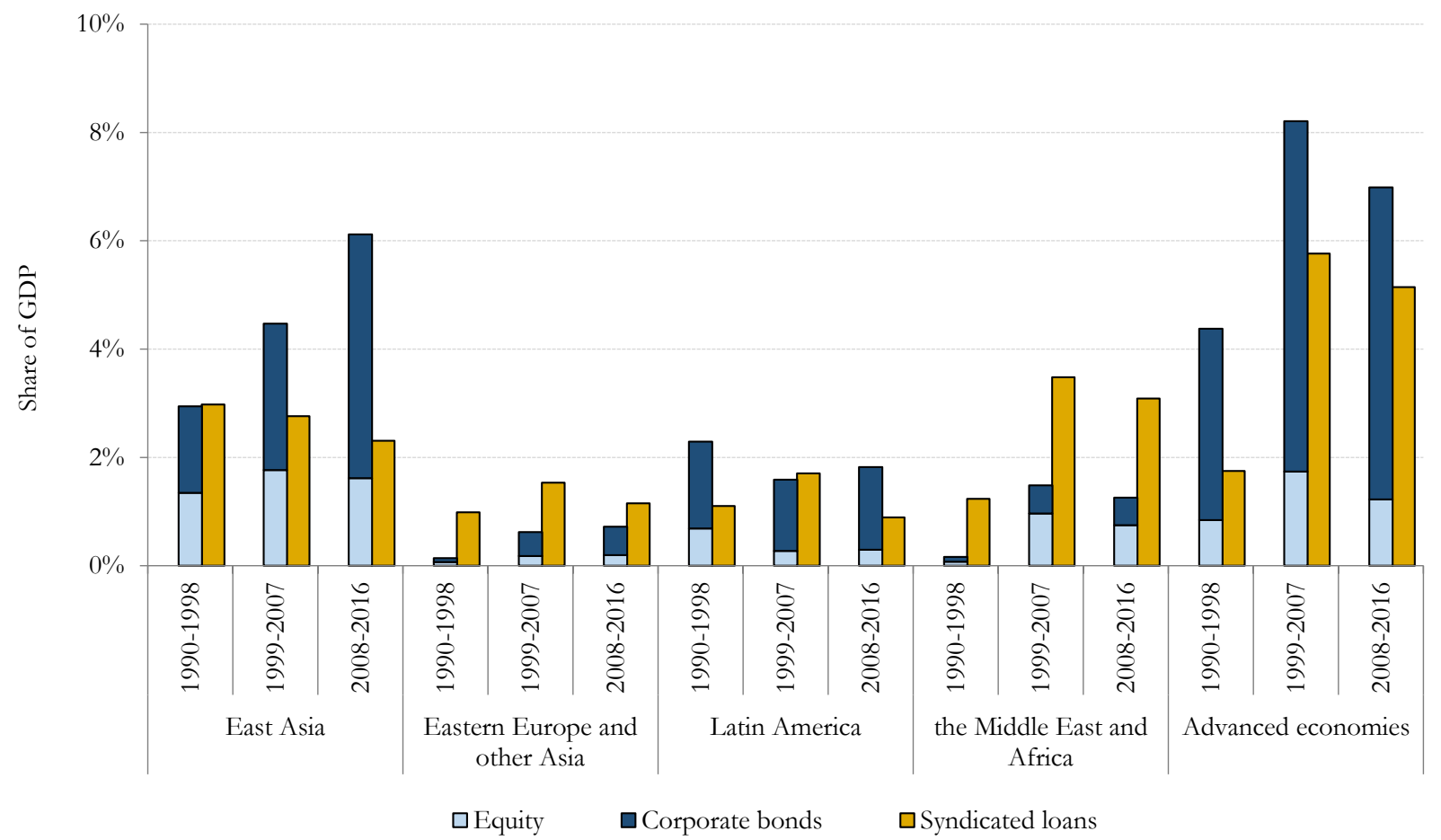

\section{B. Market Capitalization}

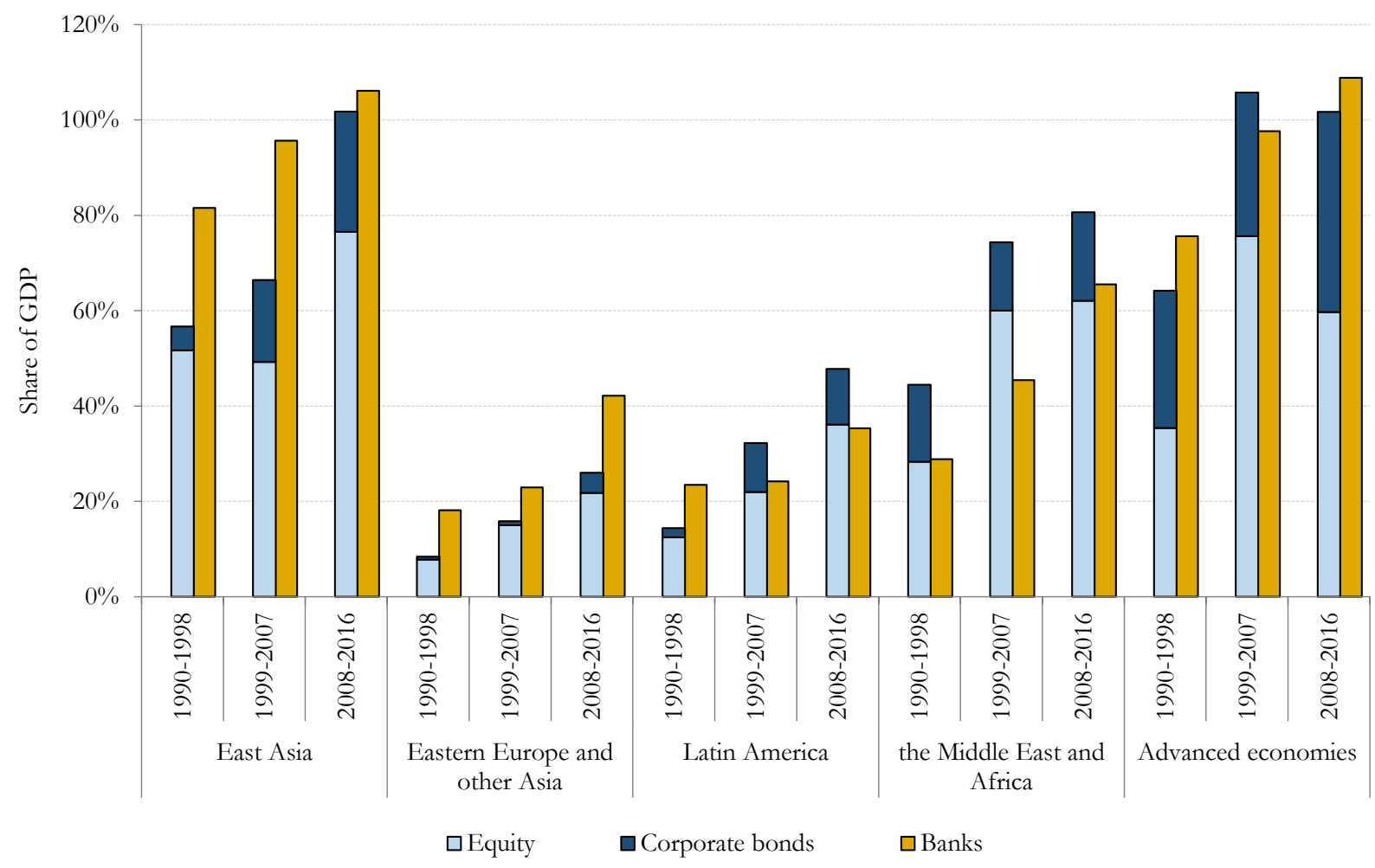


Figure 2. Share of Domestic and International Issuances

This figure shows, for the median economy in each region and period, the share of the total amount raised per year in domestic and international markets. Domestic issuances are those conducted by firms in their home economy. International issuances are those conducted by firms outside their home economy.

A. East Asia
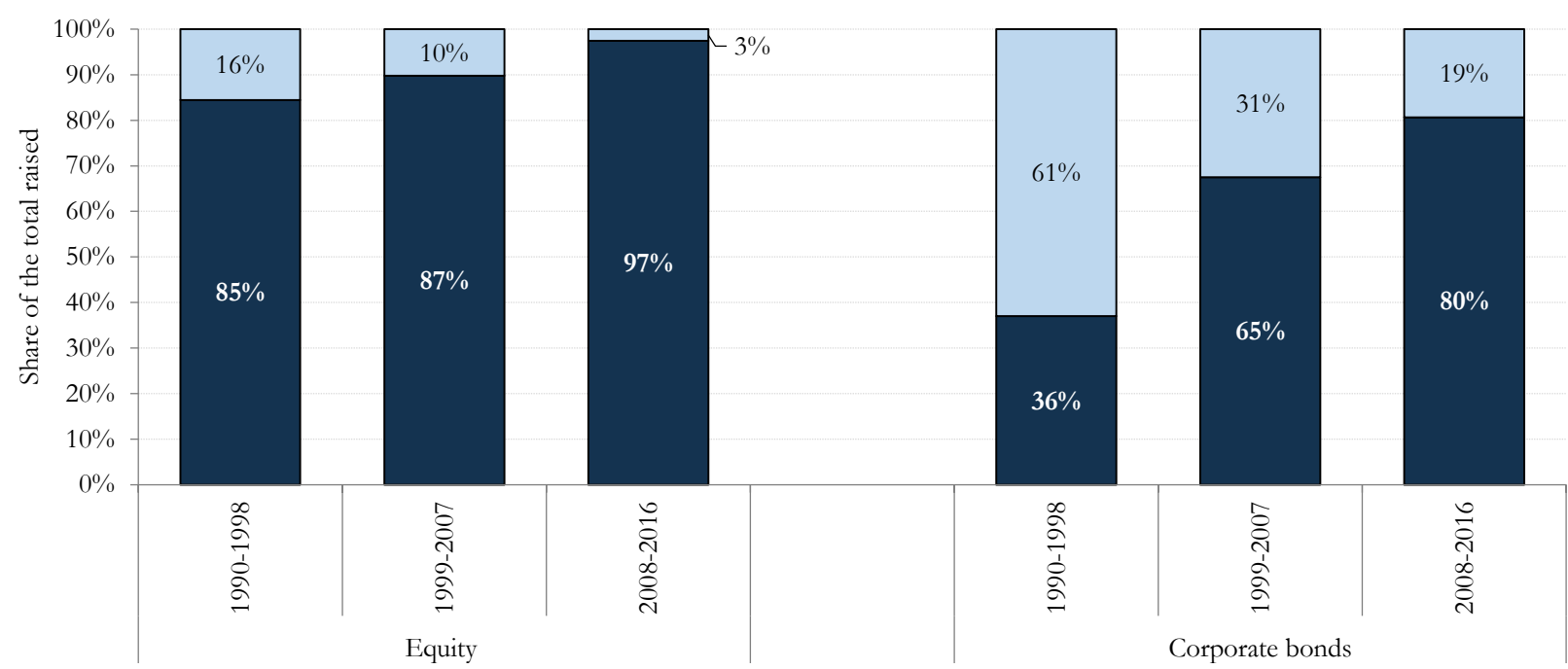

\section{B. Emerging Economies}

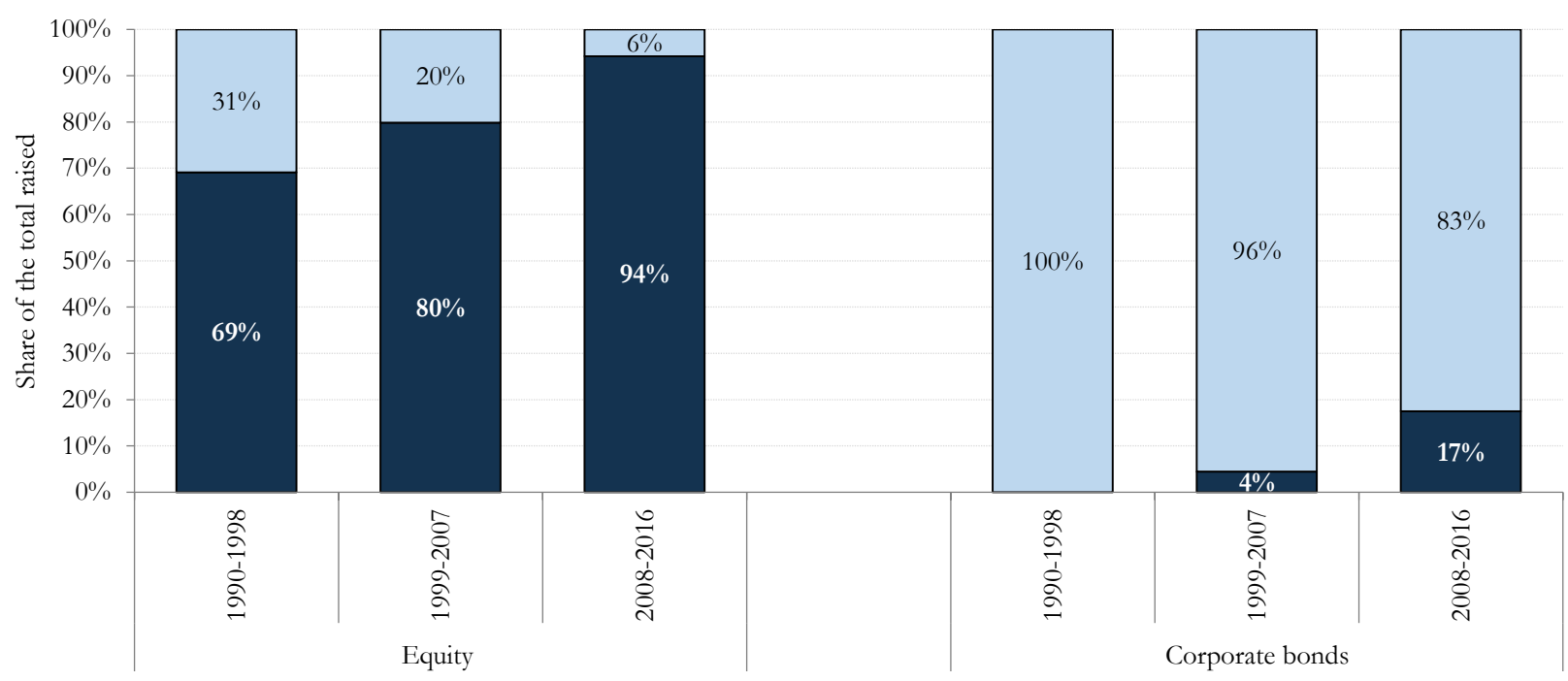

C. Advanced Economies

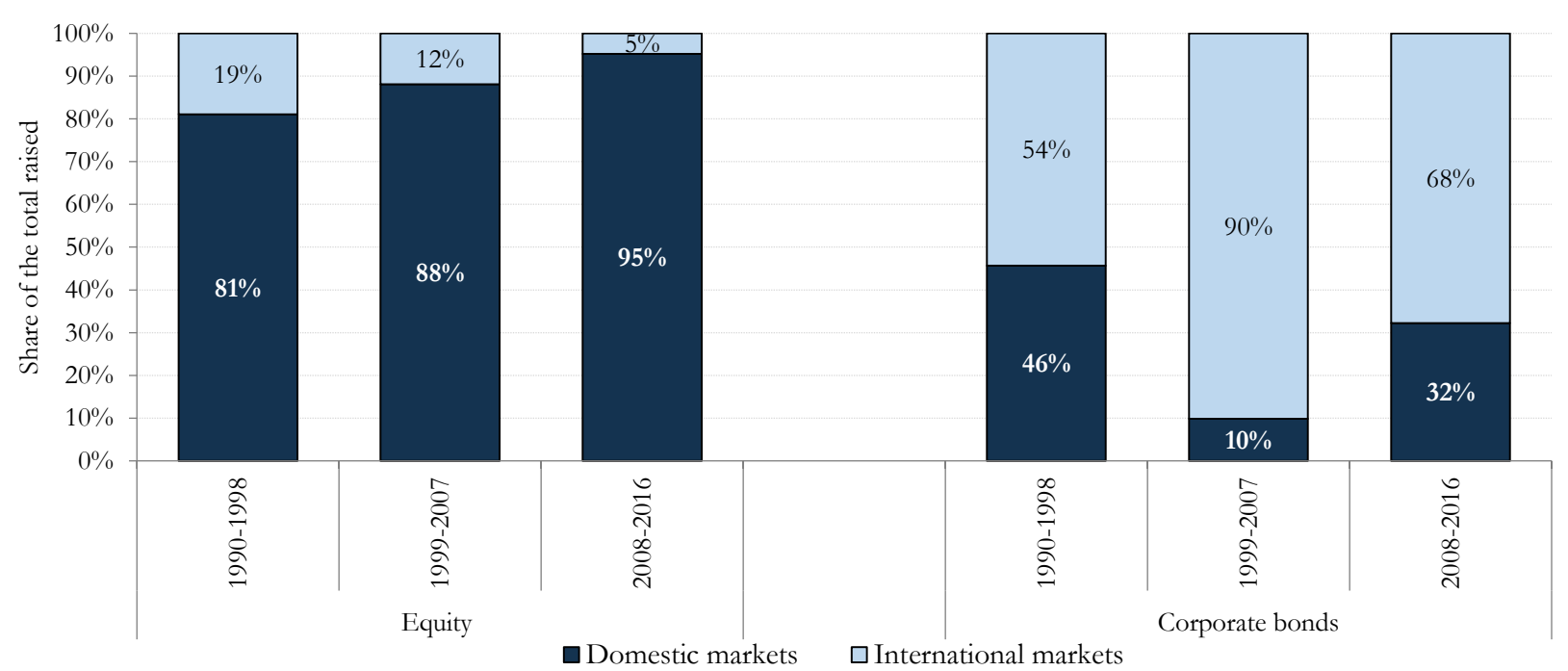




\section{Figure 3. Number of Issuing Firms}

This figure shows the growth in the number of issuing firms over 1990-2016. Panel A shows, for the median economy in each region and period, the average number of firms issuing equity and/or corporate bonds per year. Panel B shows, for the median East Asian economy in each period, the average number of firms issuing equity and corporate bonds per year in domestic and international markets.

\section{A. Number of Issuing Firms}

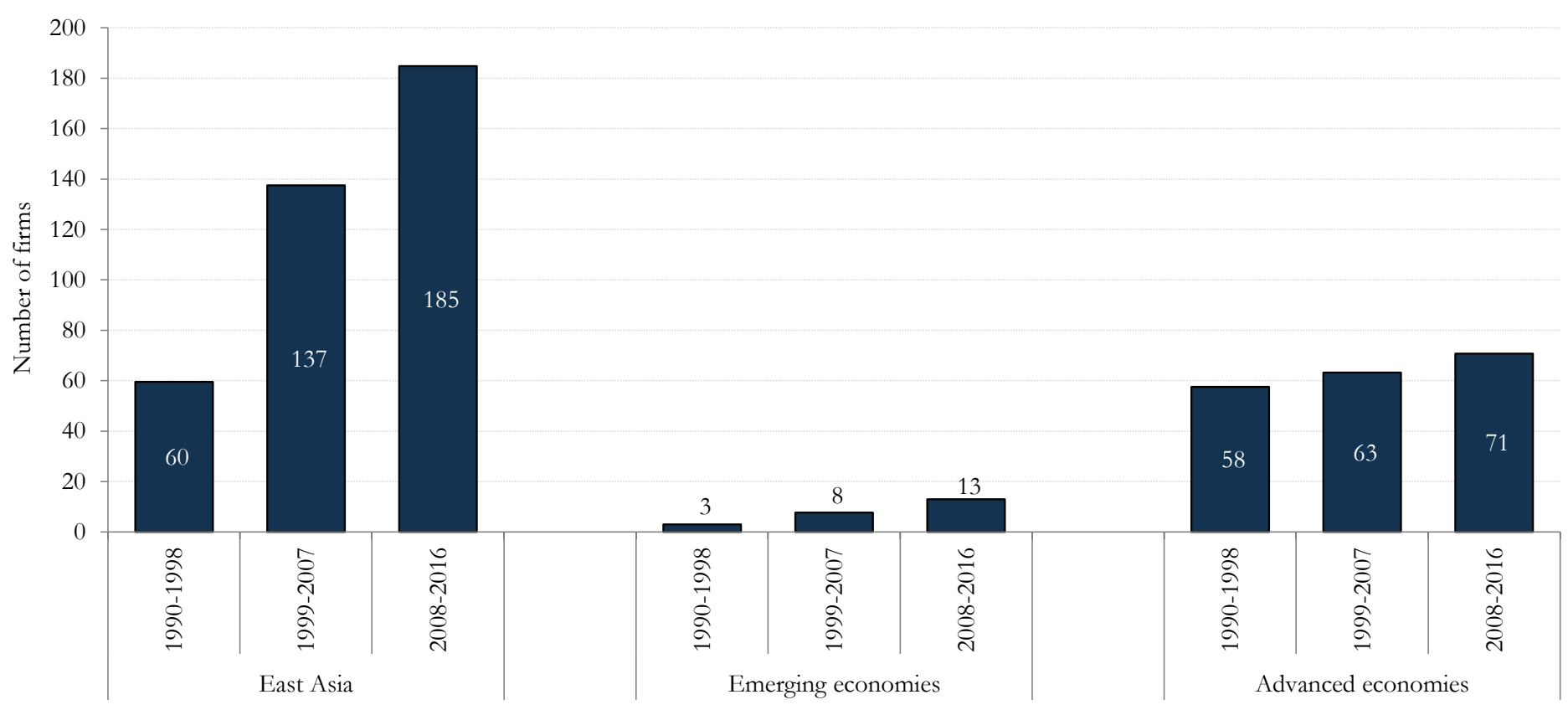

B. Number of Issuing Firms in East Asia: Domestic and International Markets

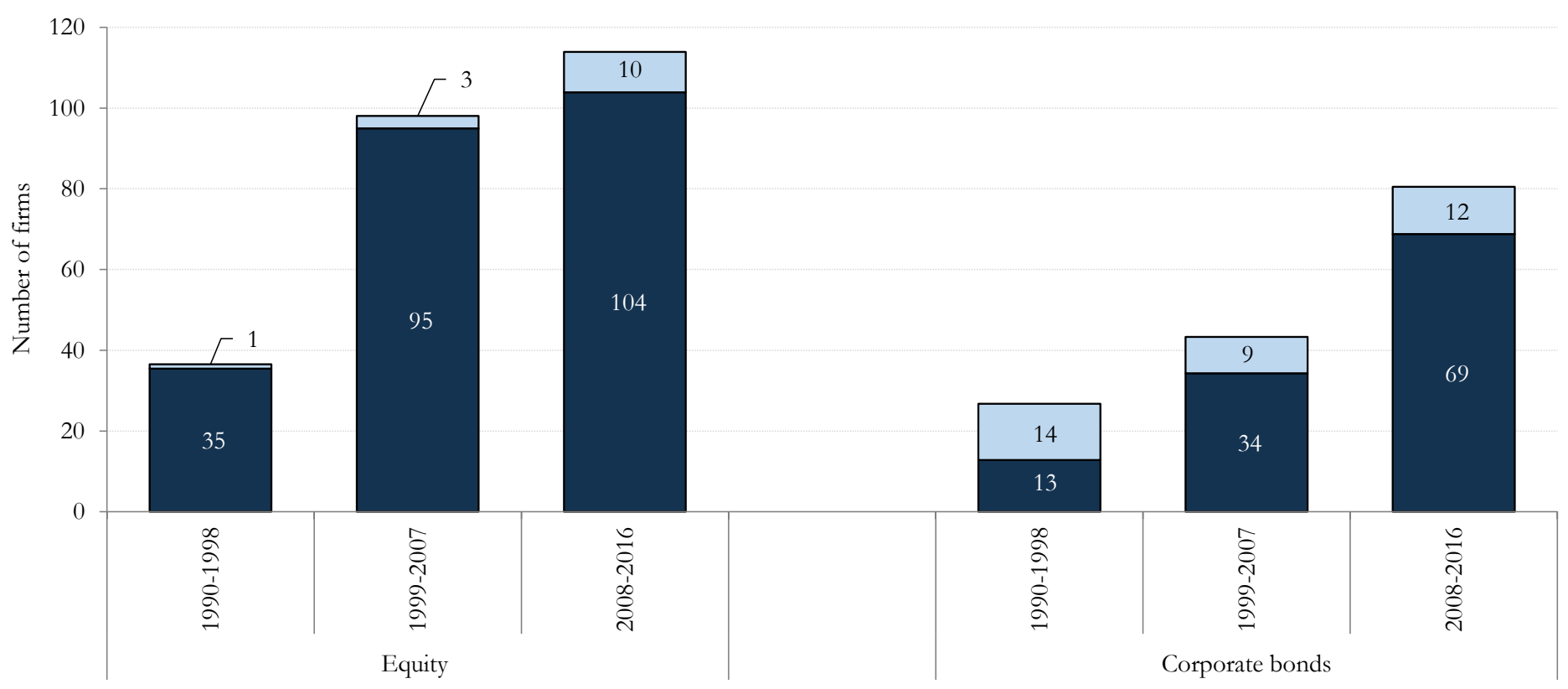

$\square$ Domestic markets $\square$ International markets 


\section{Figure 4. Size of Issuing Firms}

This figure shows, for the median economy in each region and period, the size of the median firm issuing equity and corporate bonds. Firm size is measured as the average amount raised per issuance over the whole sample period, 19902016. Values are reported in millions of constant 2011 U.S. dollars (USD).

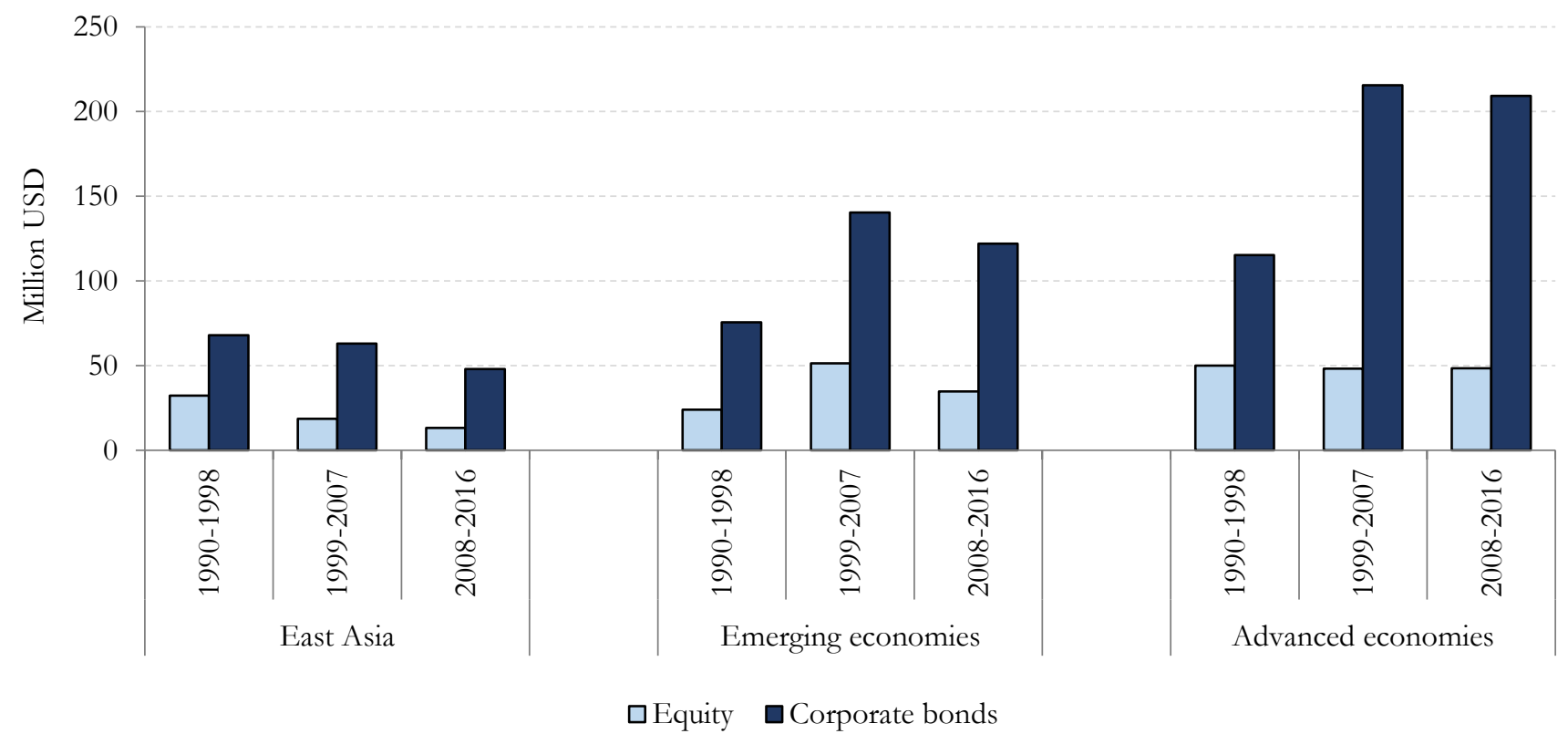




\section{Figure 5. Firm Size Distribution: Domestic and International Issuers}

This figure compares the size of East Asian firms issuing in domestic and international markets. Panels A and B show the firm size distribution of domestic and international equity and corporate bond issuers. Densities are estimated using the Epanechnikov kernel function. Panel C shows, for the median East Asian economy, the size of the median firm issuing in domestic and international markets. Firm size is measured as the average amount raised per issuance over the whole sample period, 1990-2016. Firm size values are reported in millions of constant 2011 U.S. dollars (USD).

\section{A. Equity Issuers}

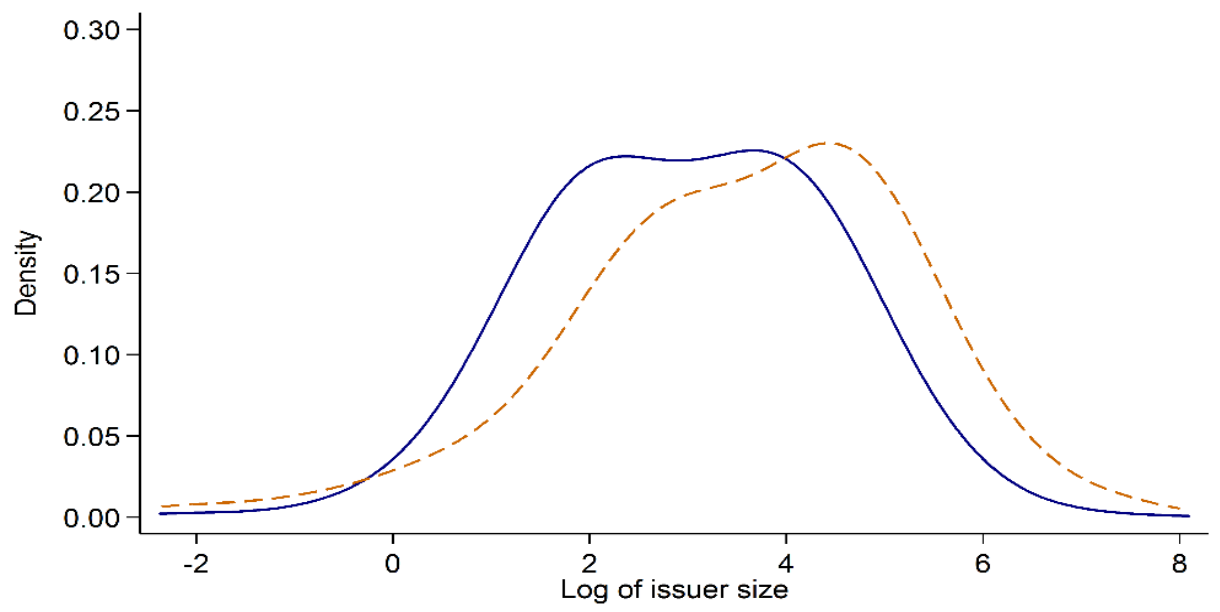

\section{B. Corporate Bond Issuers}

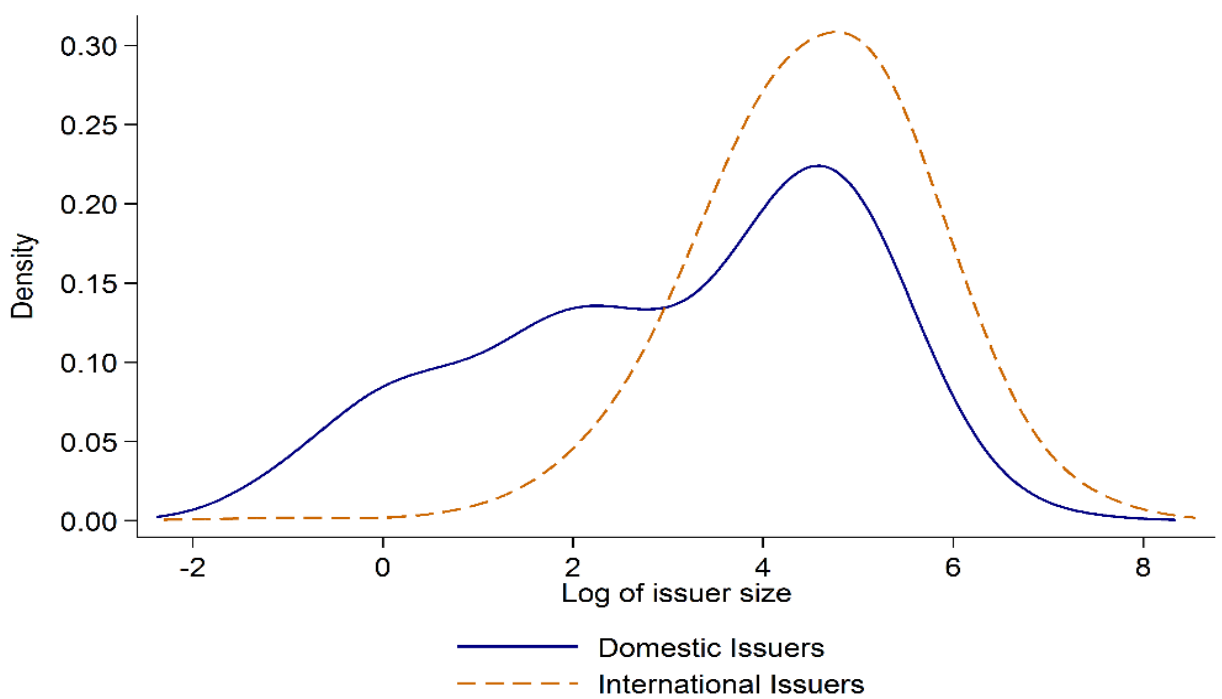

C. Median Firm Size per Market (Million USD)

\begin{tabular}{|c|c|c|c|}
\hline \multicolumn{2}{|c|}{ Equity market } & \multicolumn{2}{|c|}{ Corporate bond market } \\
\hline Domestic & International & Domestic & Internationa \\
\hline$\$ 16$ & $\$ 59$ & $\$ 32$ & $\$ 95$ \\
\hline
\end{tabular}




\section{Figure 6. Use of Different Markets by Firm Size}

This figure shows the share of East Asian firms issuing in different markets: domestic equity, domestic bonds, domestic syndicated loans, international equity, international bonds, and international syndicated loans. Issuing firms are classified into ten deciles according to their size. The first decile contains the smallest issuers and the tenth decile the largest issuers. Firm size is measured as the average amount raised per issuance over the whole sample period, 1990-2016.

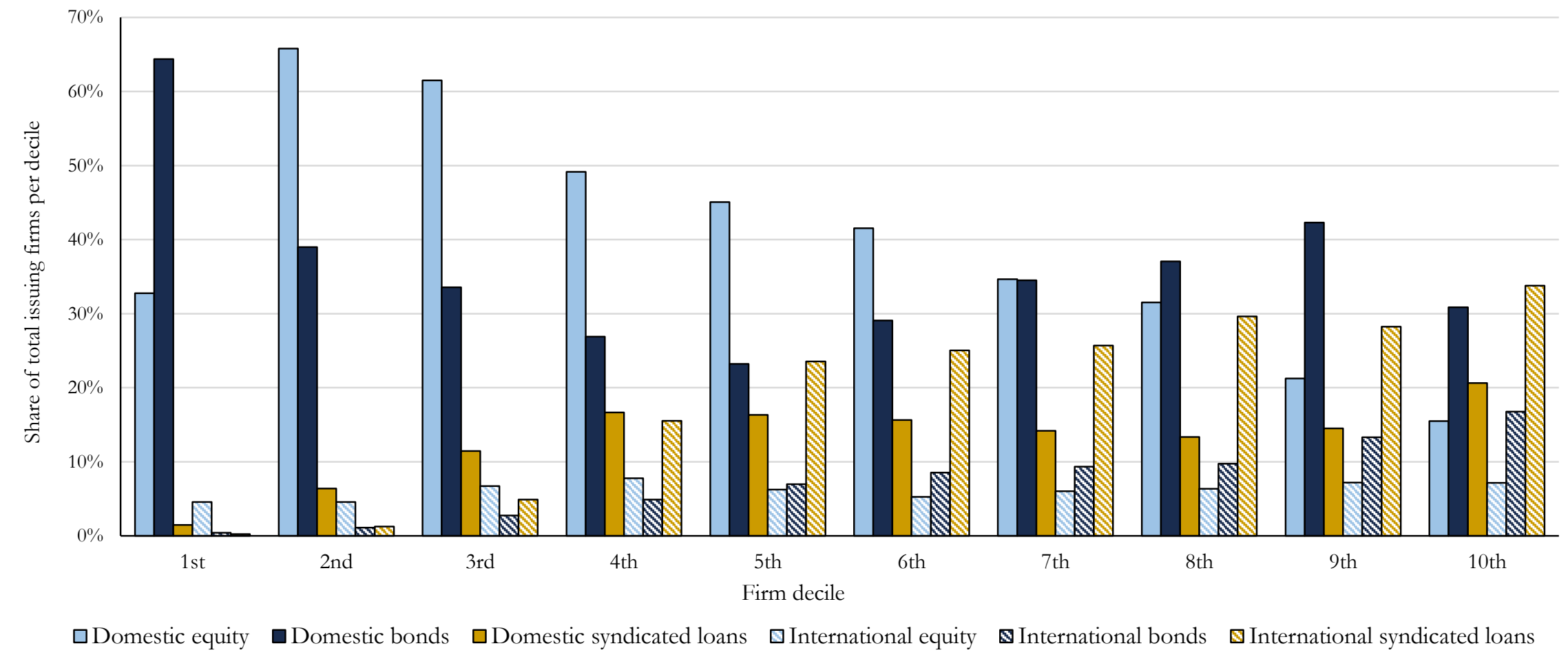




\section{Figure 7. Issuance Activity during Crises}

This figure shows the percent change in the number of corporate bond and syndicated loan issuances by East Asian firms in domestic and international markets around the Asian Financial Crisis (1997-98) and the Global Financial Crisis (2008-09). Issuance data are aggregated in two-year periods around the Asian Financial Crisis (1995-96, 1997-98, 1999-2000) and the Global Financial Crisis (2006-2007, 2008-09, 2010-11). Panel A and Panel B use data on all issuers around crises. Panel C only keeps firms that issued international debt at least once before 2008.
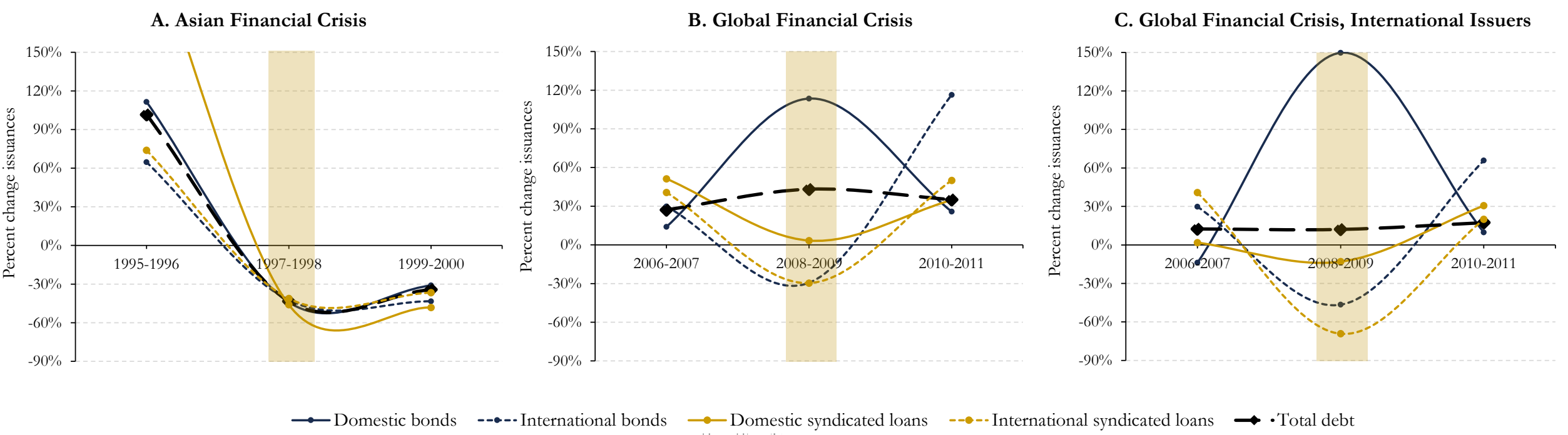

International bonds

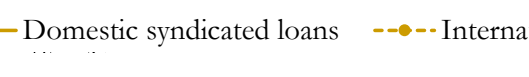

syndicated loans 


\section{Table 1. Summary Statistics}

This table shows the total number of firms, number of issuances, and amount raised per market in East Asia during 1990-2016, as well as the percentages that correspond to listed firms. The latter are those that appear listed in public stock exchanges at least once during the sample period. Unlisted firms are the rest of the firms. Amount raised values are reported in billions of constant 2011 U.S. dollars (USD).

\begin{tabular}{|c|c|c|c|c|c|c|}
\hline \multicolumn{7}{|c|}{ A. Equity } \\
\hline \multirow[b]{2}{*}{ Type of issuer } & \multicolumn{2}{|c|}{ Number of firms } & \multicolumn{2}{|c|}{ Number of issuances } & \multicolumn{2}{|c|}{$\begin{array}{l}\text { Amount raised } \\
\text { (billion USD) }\end{array}$} \\
\hline & Total & $\%$ Listed & Total & $\%$ Listed & Total & $\%$ Listed \\
\hline Domestic equity & 12,000 & $100 \%$ & 38,386 & $\overline{100 \%}$ & $\$ 2,465$ & $100 \%$ \\
\hline International equity & 1,860 & $100 \%$ & 4,810 & $100 \%$ & $\$ 770$ & $100 \%$ \\
\hline Total equity & 13,860 & $100 \%$ & 43,196 & $100 \%$ & $\$ 3,236$ & $100 \%$ \\
\hline \multicolumn{7}{|c|}{ B. Corporate Bonds } \\
\hline & \multicolumn{2}{|c|}{ Number of firms } & \multicolumn{2}{|c|}{ Number of issuances } & \multicolumn{2}{|c|}{$\begin{array}{l}\text { Amount raised } \\
\text { (billion USD) }\end{array}$} \\
\hline Type of issuer & Total & $\%$ Listed & Total & $\%$ Listed & Total & $\%$ Listed \\
\hline Domestic corporate bonds & 10,861 & $35 \%$ & 71,489 & $46 \%$ & $\$ 6,595$ & $43 \%$ \\
\hline International corporate bonds & 2,223 & $55 \%$ & 9,703 & $42 \%$ & $\$ 1,451$ & $49 \%$ \\
\hline Total corporate bonds & 13,084 & $38 \%$ & 81,194 & $45 \%$ & $\$ 8,046$ & $44 \%$ \\
\hline \multicolumn{7}{|c|}{ C. Syndicated Loans } \\
\hline & \multicolumn{2}{|c|}{ Number of firms } & \multicolumn{2}{|c|}{ Number of issuances } & \multicolumn{2}{|c|}{$\begin{array}{l}\text { Amount raised } \\
\text { (billion USD) }\end{array}$} \\
\hline Type of issuer & Total & $\%$ Listed & Total & $\%$ Listed & Total & $\%$ Listed \\
\hline Domestic syndicated loans & 3,933 & $14 \%$ & 10,112 & $32 \%$ & $\$ 1,355$ & $26 \%$ \\
\hline International syndicated loans & 5,653 & $26 \%$ & 15,316 & $38 \%$ & $\$ 2,705$ & $36 \%$ \\
\hline Total syndicated loans & 9,606 & $21 \%$ & 25,493 & $36 \%$ & $\$ 4,075$ & $33 \%$ \\
\hline
\end{tabular}




\section{Table 2. Issuance Activity}

This table shows OLS (ordinary least squares) regressions of the log of (1+amount raised) through equity and bonds per East Asian economy, industry, and year during 1990-2016 on two period dummies (1998-2007 and 2008-16). The regressions estimate total, domestic, and international issuances separately. Panel A classifies domestic and international equity and bond issuances by the residence of the issuing firm. Panel B classifies domestic and international bond issuances by (i) the nationality of the issuing firm (parent company) and (ii) the currency denomination of the issuance. The regressions include economy-industry fixed effects (FE). Standard errors are reported in brackets and are clustered at the economy-industry level. *, **, and *** indicate statistical significance at the $10 \%, 5 \%$, and $1 \%$ levels, respectively.

\section{A. Equity and Corporate Bonds}

\begin{tabular}{|c|c|c|c|c|c|c|}
\hline \multicolumn{7}{|c|}{ Dependent variable: $\log (1+$ amount raised $)$ per economy, industry, and year } \\
\hline \multirow{2}{*}{$\begin{array}{l}\text { Type of instrument: } \\
\text { Base period: } 1990-98 \\
\end{array}$} & \multicolumn{3}{|c|}{ Equity } & \multicolumn{3}{|c|}{ Corporate bonds } \\
\hline & Total & Domestic & International & Total & Domestic & International \\
\hline Period 1999-07 & $\begin{array}{l}0.58 \text { *** } \\
{[0.16]}\end{array}$ & $\begin{array}{l}0.48 \text { *** } \\
{[0.17]}\end{array}$ & $\begin{array}{l}0.64 \text { *** } \\
{[0.18]}\end{array}$ & $\begin{array}{l}1.18 \text { *** } \\
{[0.19]}\end{array}$ & $\begin{array}{l}2.03 * * * \\
{[0.22]}\end{array}$ & $\begin{array}{l}-0.08 \\
{[0.18]}\end{array}$ \\
\hline Period 2008-16 & $\begin{array}{l}1.80 * * * \\
{[0.16]}\end{array}$ & $\begin{array}{l}1.87 * * * \\
{[0.15]}\end{array}$ & $\begin{array}{l}0.73 * * * \\
{[0.25]}\end{array}$ & $\begin{array}{l}2.77^{* * *} \\
{[0.28]}\end{array}$ & $\begin{array}{l}3.81 * * * \\
{[0.31]}\end{array}$ & $\begin{array}{l}0.58^{* *} \\
{[0.25]}\end{array}$ \\
\hline Economy-industry FE & Yes & Yes & Yes & Yes & Yes & Yes \\
\hline No. of observations & 2,079 & 2,079 & 2,079 & 2,079 & 2,079 & 2,079 \\
\hline No. of clusters & 90 & 90 & 90 & 90 & 90 & 90 \\
\hline R-squared & 0.58 & 0.55 & 0.50 & 0.60 & 0.61 & 0.54 \\
\hline \multicolumn{7}{|c|}{ B. Corporate Bonds: Alternative Definitions of International Issuances } \\
\hline \multicolumn{7}{|c|}{ Dependent variable: $\log (1+$ amount raised $)$ per economy, industry, and year } \\
\hline Alternative definition: & \multicolumn{3}{|c|}{ Nationality of issuer } & \multicolumn{3}{|c|}{ Currency denomination } \\
\hline Base period: $1990-98$ & Total & Domestic & International & Total & Domestic & International \\
\hline Period 1999-07 & $\begin{array}{r}0.23 \\
{[0.14]}\end{array}$ & $\begin{array}{l}1.68 * * * \\
{[0.24]}\end{array}$ & $\begin{array}{l}-0.79 * * * \\
{[0.26]}\end{array}$ & $\begin{array}{l}1.18 * * * \\
{[0.19]}\end{array}$ & $\begin{array}{l}2.05 * * * \\
{[0.21]}\end{array}$ & $\begin{array}{r}-0.10 \\
{[0.19]}\end{array}$ \\
\hline Period 2008-16 & $\begin{array}{l}1.25^{* * *} \\
{[0.18]}\end{array}$ & $\begin{array}{l}3.13 * * * \\
{[0.29]}\end{array}$ & $\begin{array}{r}-0.24 \\
{[0.29]}\end{array}$ & $\begin{array}{l}2.77 * * * \\
{[0.28]}\end{array}$ & $\begin{array}{l}3.73 * * * \\
{[0.30]}\end{array}$ & $\begin{array}{l}0.78^{* * *} \\
{[0.25]}\end{array}$ \\
\hline Economy-industry FE & Yes & Yes & Yes & Yes & Yes & Yes \\
\hline No. of observations & 1,429 & 1,429 & 1,429 & 2,079 & 2,079 & 2,079 \\
\hline No. of clusters & 85 & 85 & 85 & 90 & 90 & 90 \\
\hline $\mathrm{R}$-squared & 0.69 & 0.59 & 0.52 & 0.60 & 0.60 & 0.54 \\
\hline
\end{tabular}




\section{Table 3. Share Raised in Domestic Markets}

This table shows regressions estimating changes in the share of the total amount raised in domestic equity and corporate bond markets in East Asia over time. Column A reports OLS regressions of the share of the total amount raised in domestic markets per economy, industry, and year during 1990-2016 on two period dummies (1998-2007 and 2008-16). The "mean, 1990-98" estimates correspond to the average of the annual share of equity/bonds raised domestically across economyindustry observations during 1990-98. Column B reports WLS (weighted least squares) regressions of the share of the total amount raised in domestic markets per firm and year during 1990-2016 on two period dummies (1998-2007 and 2008-16). The "mean, 1990-98" estimates correspond to the weighted average of the annual share of equity/bonds raised domestically across firms during 1990-98. Each observation is weighted by one over the total number of equity/bond issuers per economy, industry, and period. The sum of the weights of all observations per economy, industry, and period equals one. The regressions include, alternatively, economy-industry fixed effects (FE) and firm fixed effects (FE). Standard errors are reported in brackets and are clustered at the economy-industry level. *, **, and $* * *$ denote statistical significance at 10\%, 5\%, and $1 \%$, respectively.

\begin{tabular}{|c|c|c|c|c|}
\hline Level of aggregation: & A. Econo & -Industry & & \\
\hline Dependent variable: & $\begin{array}{l}\text { Share of the tota } \\
\text { markets per econo }\end{array}$ & $\begin{array}{l}\text { ised in domestic } \\
\text { industry, and year }\end{array}$ & $\begin{array}{r}\text { Share of the to } \\
\text { markets } \mathrm{p}\end{array}$ & $\begin{array}{l}\text { ised in domestic } \\
\mathrm{m} \text { and year }\end{array}$ \\
\hline Type of instrument: & Equity & Corporate bonds & Equity & Corporate bonds \\
\hline Mean, 1990-98: & 0.72 & 0.21 & 0.89 & 0.39 \\
\hline Period 1999-07 & $\begin{array}{r}0.04 \\
{[0.03]}\end{array}$ & $\begin{array}{l}0.28 \text { *** } \\
{[0.03]}\end{array}$ & $\begin{array}{r}0.02 \\
{[0.01]}\end{array}$ & $\begin{array}{l}0.22 \text { *** } \\
{[0.04]}\end{array}$ \\
\hline Period 2008-16 & $\begin{array}{l}0.19 * * * \\
{[0.03]}\end{array}$ & $\begin{array}{l}0.48^{* * *} \\
{[0.03]}\end{array}$ & $\begin{array}{l}0.03 * * \\
{[0.01]}\end{array}$ & $\begin{array}{l}0.28 \text { *** } \\
{[0.05]}\end{array}$ \\
\hline Economy-industry FE & Yes & Yes & No & No \\
\hline Firm FE & No & No & Yes & Yes \\
\hline No. of observations & 2,079 & 2,079 & 22,594 & 21,827 \\
\hline No. of clusters & 90 & 90 & 87 & 80 \\
\hline R-squared & 0.23 & 0.41 & 0.86 & 0.73 \\
\hline
\end{tabular}




\section{Table 4. Extensive Margin: Number of Firms Issuing}

This table shows OLS regressions of the log of (1+the number of issuers) in equity and corporate bond markets per East Asian economy, industry, and year during 1990-2016 on two period dummies (1998-2007 and 2008-16). The regressions estimate total, domestic, and international issuers separately. The regressions include economy-industry fixed effects (FE). Standard errors are reported in brackets and are clustered at the economy-industry level. *, **, and *** indicate statistical significance at the $10 \%, 5 \%$, and $1 \%$ levels, respectively.

\begin{tabular}{|c|c|c|c|c|c|c|}
\hline \multicolumn{7}{|c|}{ Dependent variable: $\log (1+$ number of issuers $)$ per economy, industry, and year } \\
\hline \multirow{2}{*}{$\begin{array}{l}\text { Type of instrument: } \\
\text { Base period: } 1990-98 \\
\end{array}$} & \multicolumn{3}{|c|}{ Equity } & \multicolumn{3}{|c|}{ Corporate bonds } \\
\hline & Total & Domestic & International & Total & Domestic & International \\
\hline \multirow[t]{2}{*}{ Period 1999-07 } & $0.51 * * *$ & $0.47 * * *$ & $0.19 * * *$ & $0.34 * * *$ & $0.53 * * *$ & -0.06 \\
\hline & {$[0.08]$} & [0.09] & [0.05] & {$[0.06]$} & {$[0.07]$} & {$[0.05]$} \\
\hline \multirow[t]{2}{*}{ Period 2008-16 } & $1.06 * * *$ & $1.02 * * *$ & $0.35 * * *$ & $1.03 * * *$ & $1.25 * * *$ & $0.11 *$ \\
\hline & {$[0.09]$} & {$[0.09]$} & [0.09] & {$[0.11]$} & {$[0.13]$} & {$[0.06]$} \\
\hline Economy-industry FE & Yes & Yes & Yes & Yes & Yes & Yes \\
\hline No. of observations & 2,079 & 2,079 & 2,079 & 2,079 & 2,079 & 2,079 \\
\hline No. of clusters & 90 & 90 & 90 & 90 & 90 & 90 \\
\hline R-squared & 0.71 & 0.69 & 0.59 & 0.68 & 0.64 & 0.65 \\
\hline
\end{tabular}




\section{Table 5. Size of Equity and Corporate Bond Issuers}

This table shows OLS regressions of the size of East Asian equity and corporate bond issuers during 1990-2016 on two period dummies (1999-07 and 2008-16). The dependent variable is the median issuer size (in logs) per economy, industry, and period. Firm size is measured as the average amount raised per issuance over the whole sample period, 1990-2016. The regressions include economy-industry fixed effects (FE). Standard errors are reported in brackets and are clustered at the economy-industry level. *, **, and $* * *$ denote statistical significance at $10 \%, 5 \%$, and $1 \%$, respectively.

\begin{tabular}{|c|c|c|c|c|c|c|}
\hline \multirow{2}{*}{$\begin{array}{c}\text { Type of instrument: } \\
\text { Base period: 1990-98 } \\
\end{array}$} & \multicolumn{3}{|c|}{ Equity } & \multicolumn{3}{|c|}{ Corporate bonds } \\
\hline & Total & Domestic & International & Total & Domestic & International \\
\hline Period 1999-07 & $\begin{array}{l}-0.43 * * * \\
{[0.09]}\end{array}$ & $\begin{array}{l}-0.44 * * * \\
{[0.09]}\end{array}$ & $\begin{array}{r}-0.18 \\
{[0.23]}\end{array}$ & $\begin{array}{r}0.06 \\
{[0.10]}\end{array}$ & $\begin{array}{r}0.03 \\
{[0.11]}\end{array}$ & $\begin{array}{c}0.23 * \\
{[0.12]}\end{array}$ \\
\hline Period 2008-16 & $\begin{array}{l}-0.59 * * * \\
{[0.11]}\end{array}$ & $\begin{array}{l}-0.56 * * * \\
{[0.11]}\end{array}$ & $\begin{array}{l}-0.70 * * * \\
{[0.25]}\end{array}$ & $\begin{array}{l}-0.33 * * * \\
{[0.12]}\end{array}$ & $\begin{array}{l}-0.30 * * * \\
{[0.11]}\end{array}$ & $\begin{array}{r}0.14 \\
{[0.15]}\end{array}$ \\
\hline Economy-industry FE & Yes & Yes & Yes & Yes & Yes & Yes \\
\hline No. of observations & 253 & 252 & 175 & 246 & 234 & 217 \\
\hline No. of clusters & 88 & 88 & 70 & 88 & 87 & 80 \\
\hline R-squared & 0.86 & 0.84 & 0.71 & 0.80 & 0.79 & 0.69 \\
\hline
\end{tabular}




\section{Appendix Figure 1. Firm Size Proxy}

Panel A shows, for publicly listed East Asian firms, the correlation between asset size and issuance size. Assets (in logs) and amount raised (in logs) are the average within firms over the whole sample period, 1990-2016. Panel B shows the firm size distribution of listed and unlisted corporate bond issuers in East Asia. Firm size (in logs) is the average amount raised per issuance over the whole sample period, 1990-2016. Densities are estimated using the Epanechnikov kernel function. Listed firms are those that appear as listed in public stock exchanges at least once during the sample period. Unlisted firms are the rest of the firms.

\section{A. Average Assets vs. Average Amount Raised}

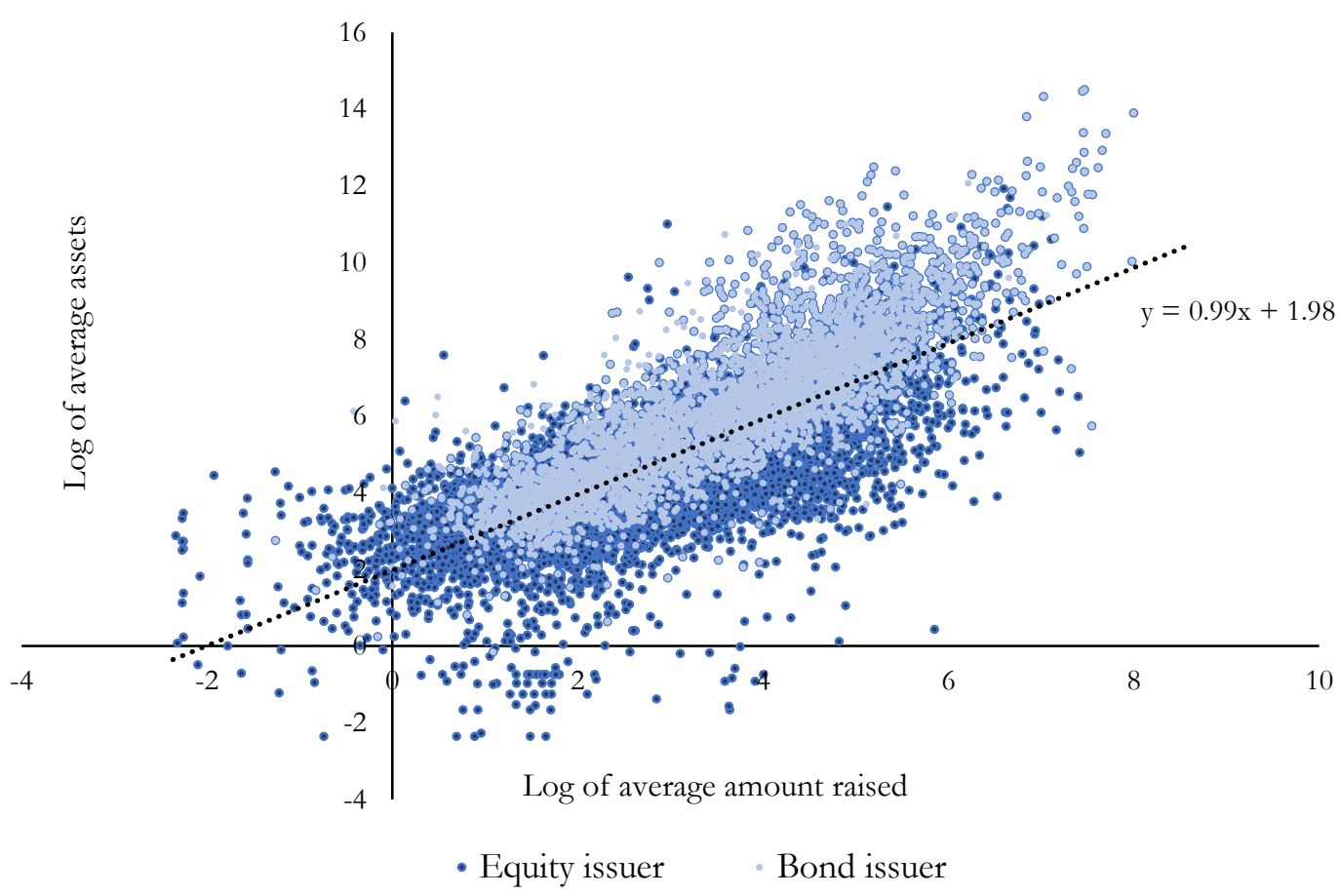

\section{B. Firm Size Distribution of Listed and Unlisted Bond Issuers}

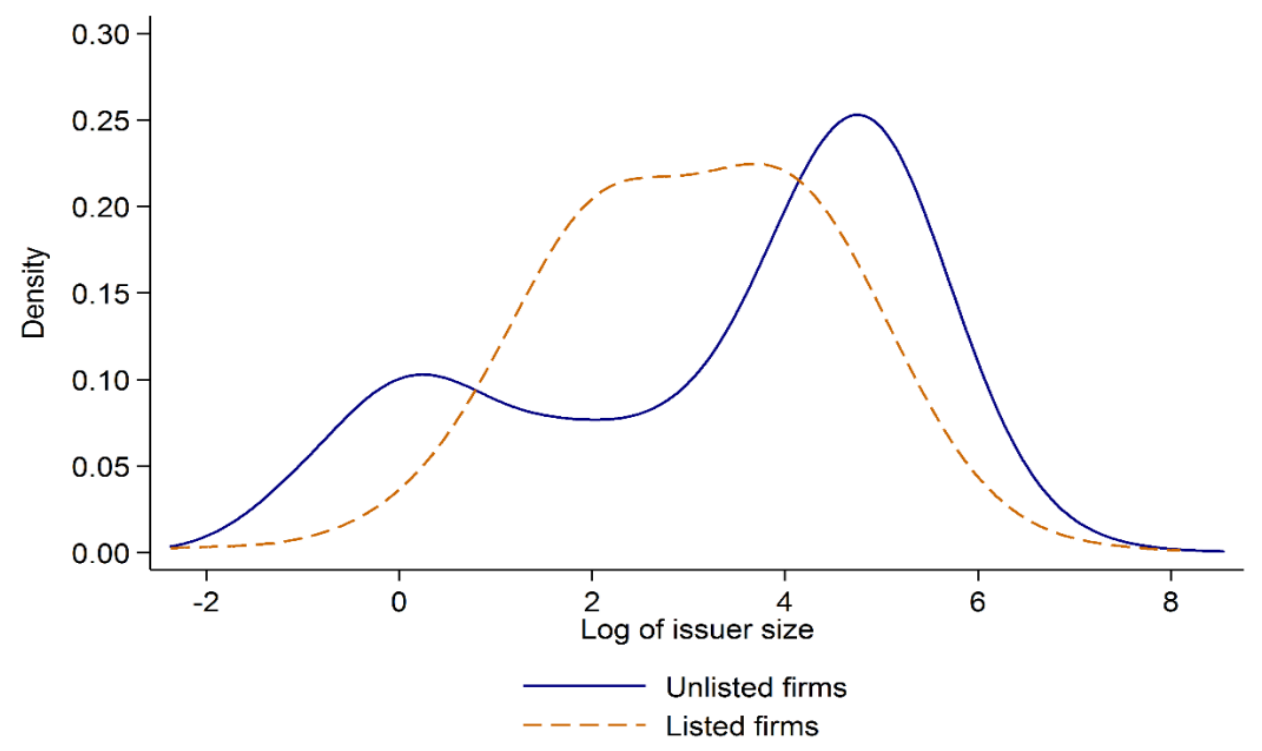




\section{Appendix Figure 2. Growth in Equity and Bond Financing: East Asian Economies}

This figure shows the evolution of capital markets and banks over 1990-2016. Panel A shows, for each East Asian economy and period, the amount of equity, corporate bonds, and syndicated loans raised per year as a percentage of GDP. Panel B shows, for each East Asian economy and period, the average size of financial markets as a percentage of GDP. In Panel B, "equity" refers to stock market capitalization, "corporate bonds" to the amount outstanding of domestic private bonds, and "banks" to the oustanding amount of private credit granted by domestic banks. The market capitalization data come from the World Bank Financial Development and Structure Dataset (version June 2017).

\section{A. Total Amount Raised}

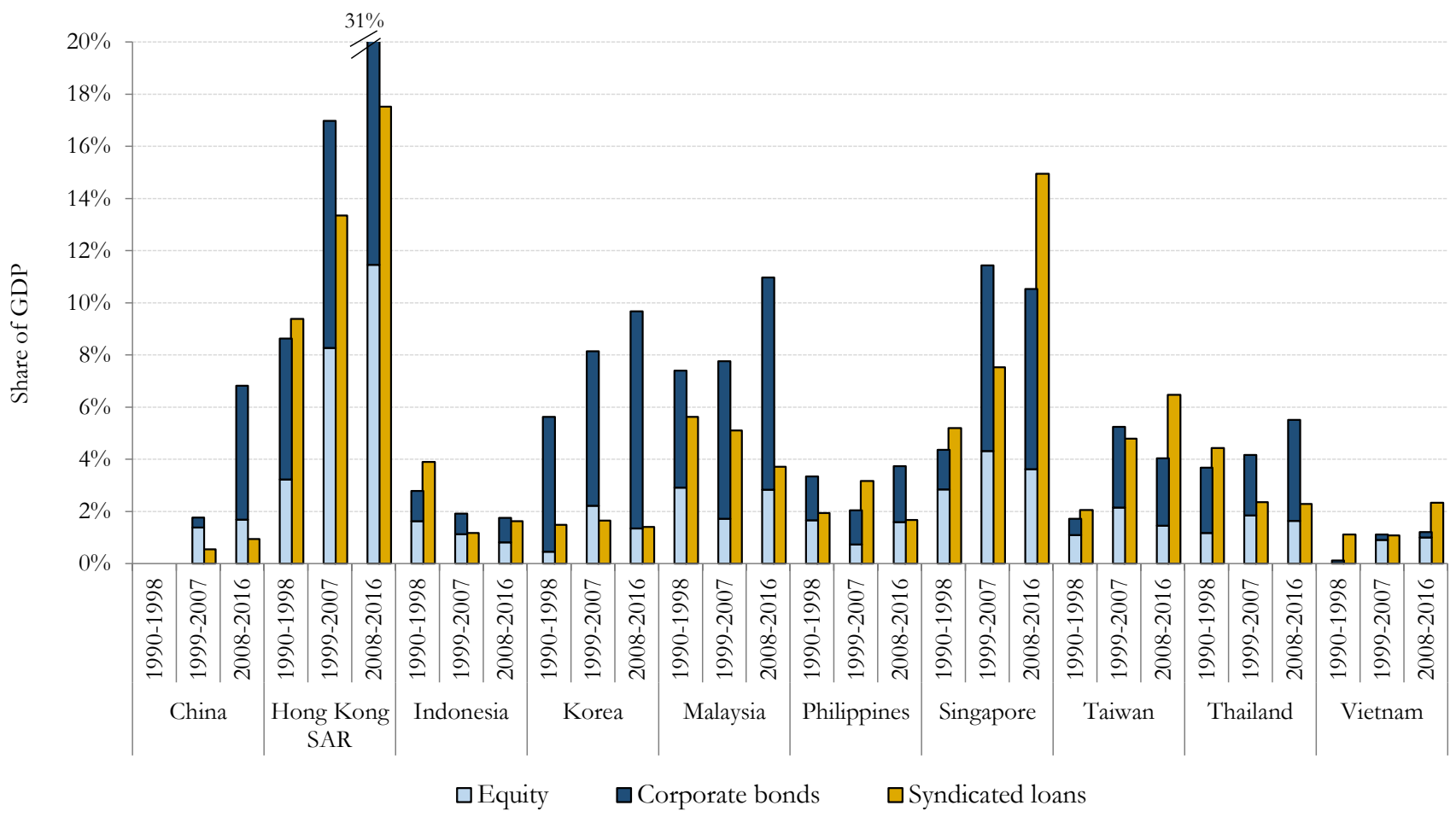

\section{B. Market Capitalization}

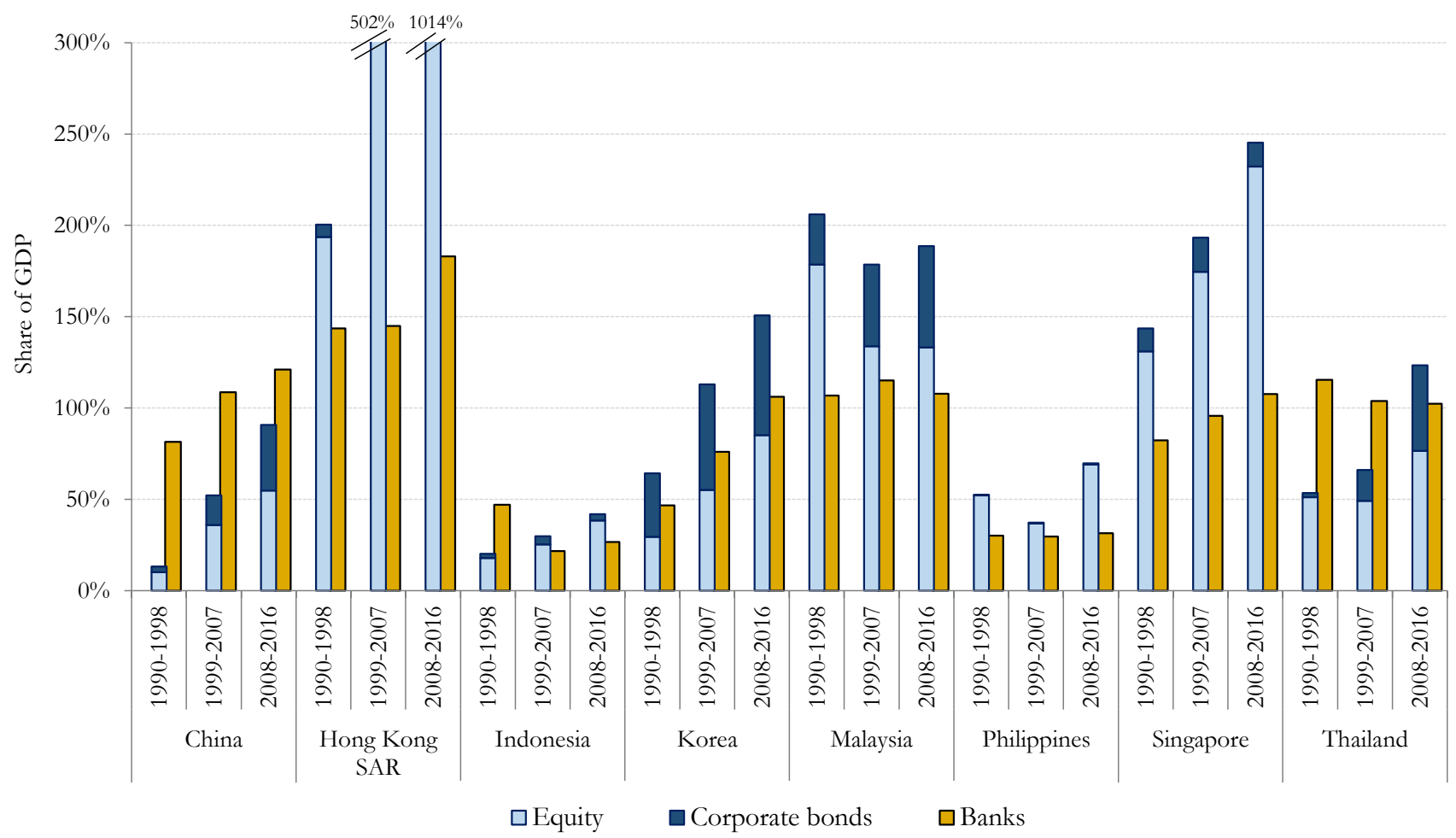




\section{Appendix Figure 3. Share of Domestic and International Issuances: East Asian Economies}

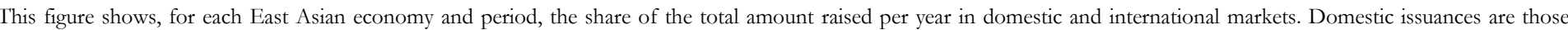
conducted by firms in their home economy. International issuances are those conducted by firms outside their home economy.

A. Equity

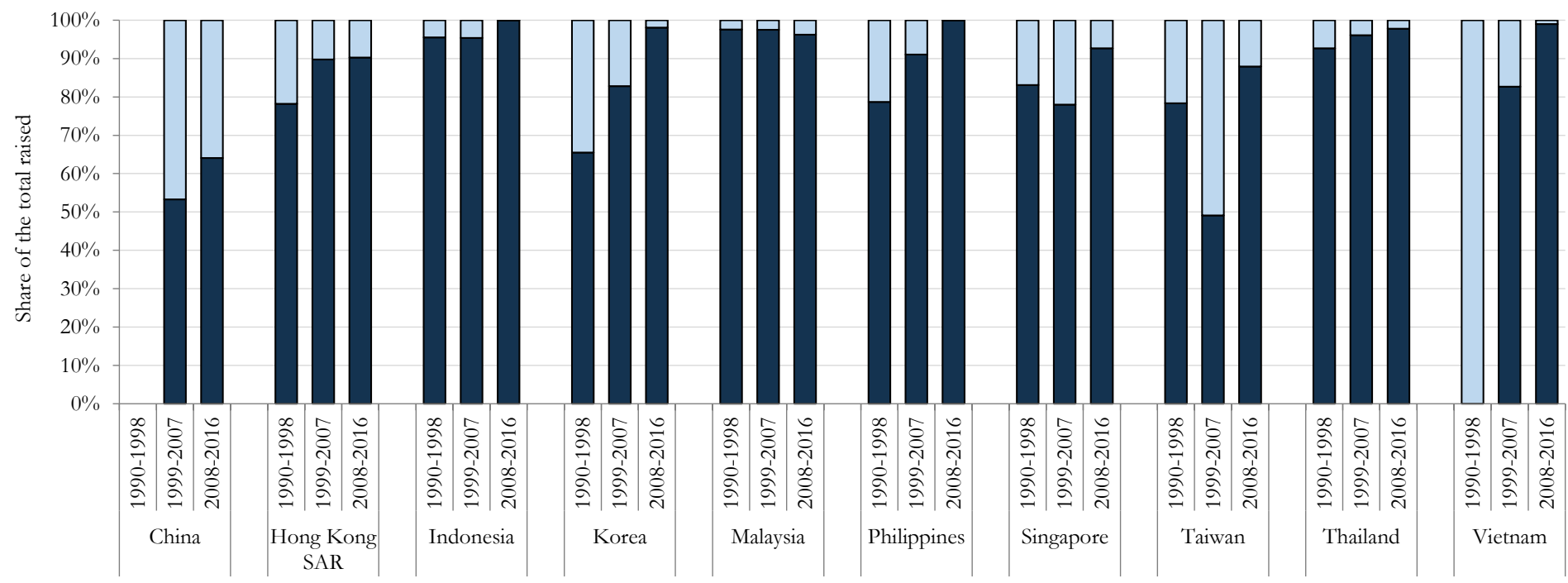

B. Corporate Bonds

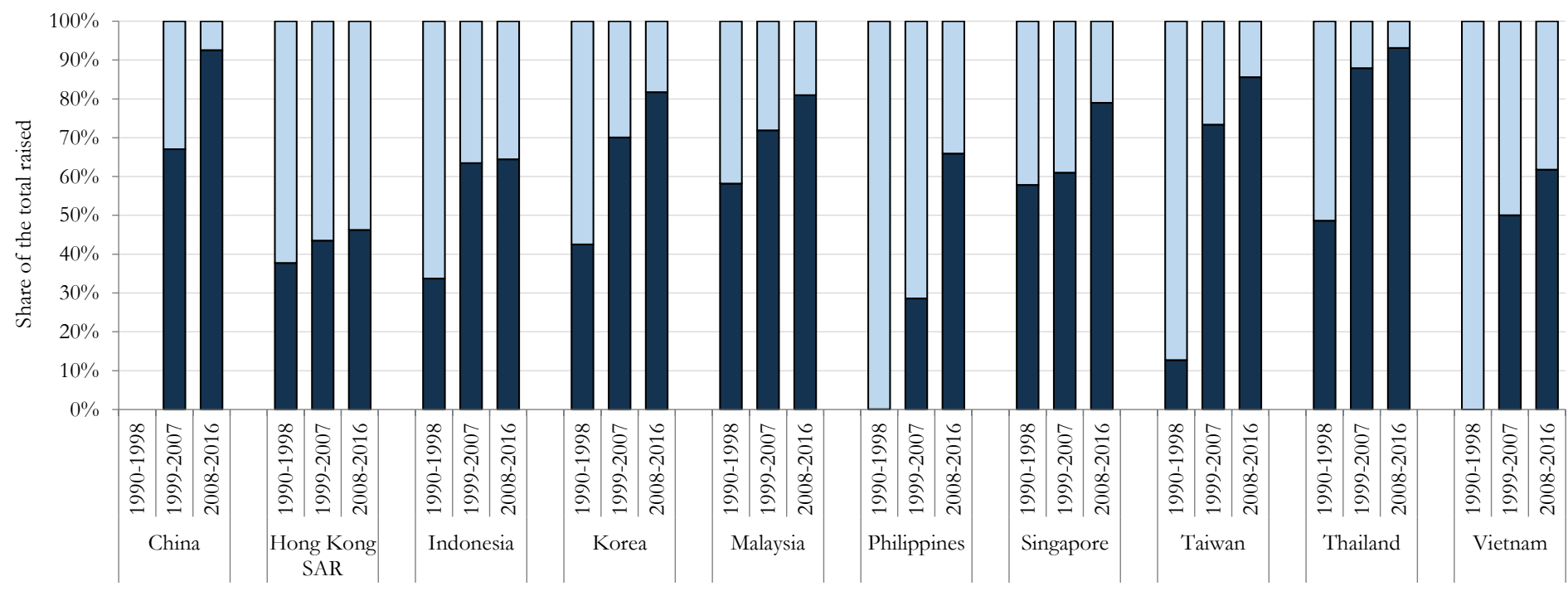

口Domestic markets

$\square$ International markets 


\section{Appendix Figure 4. Number of Capital Market Reforms in East Asia per Year}

The figure shows 68 reforms compiled for Indonesia, Korea, Rep., Malaysia, the Philippines, and Vietnam since the 1997-98 Asian Financial Crisis. To compile these reforms, we received help from the World Bank Office of the Chief Economist for East Asia and Pacific and financial sector experts in the region.

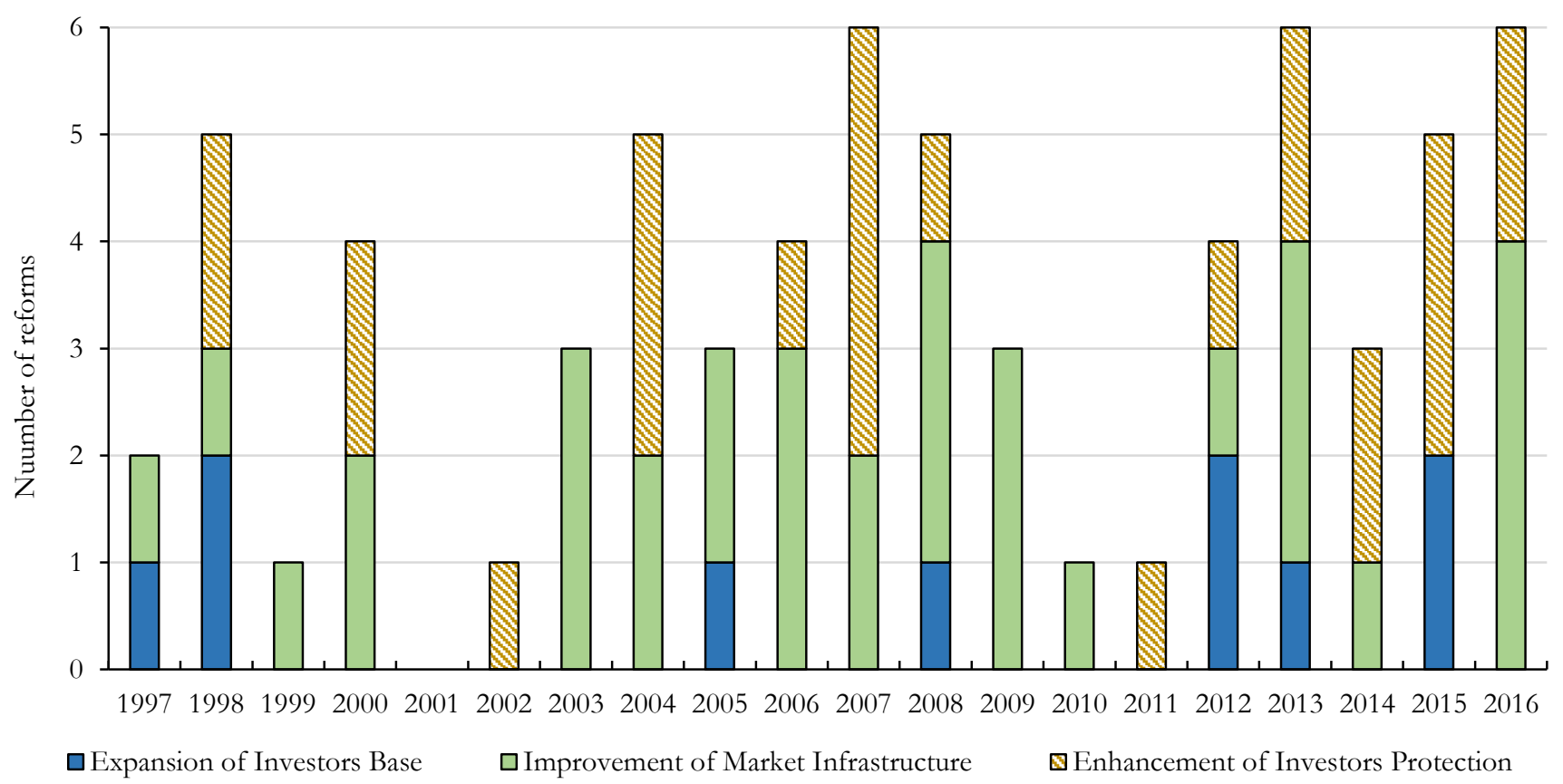




\section{Appendix Figure 5. Amount Raised by Sector: Traditional vs. SME Capital Markets}

This figure shows, for each market, the share of the total equity raised by each sector during 2004-16. Only data on IPO issuances are included for TPEx. Other services include: business services, hotels, health services, legal services, and repair services, among other professional services. Other sectors include: agriculture, forestry, and fishing; construction; mining; and wholesale and retail.

\section{A. Traditional Markets}

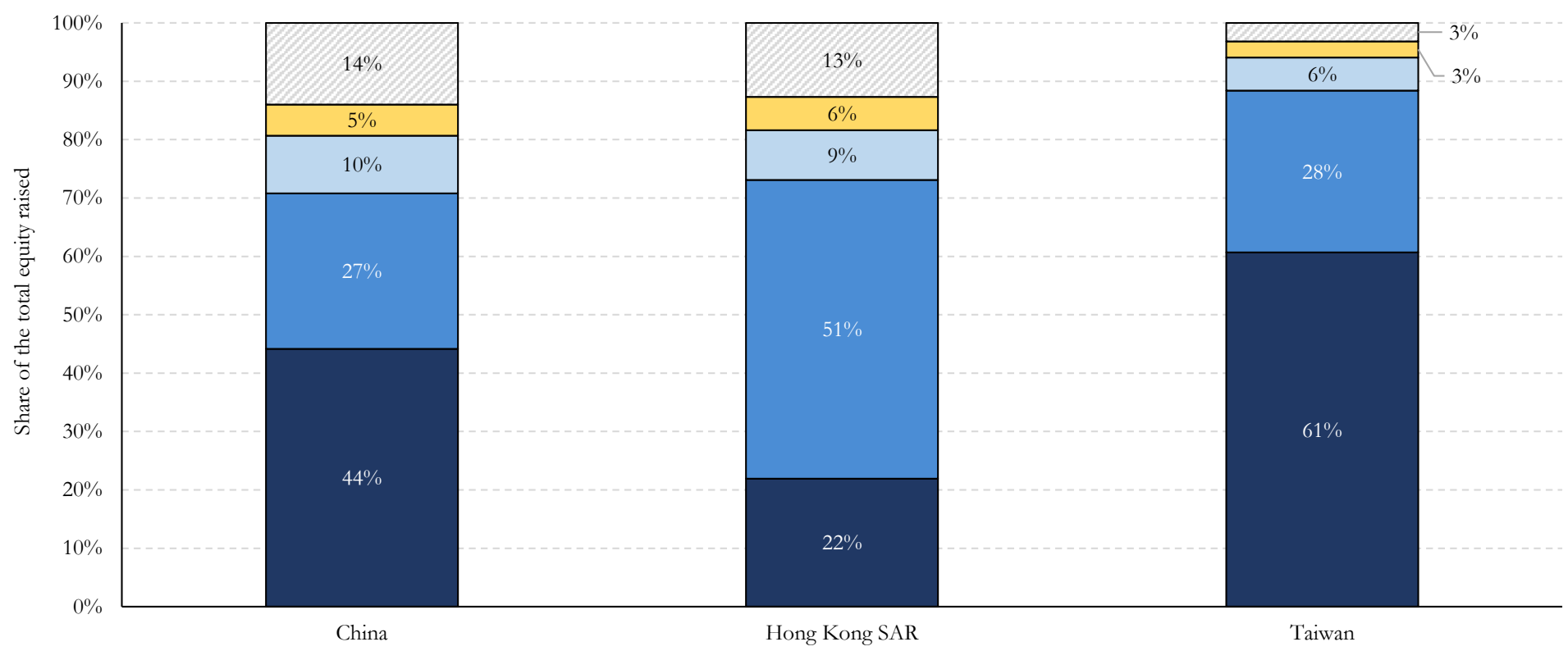

\section{B. SME Markets}

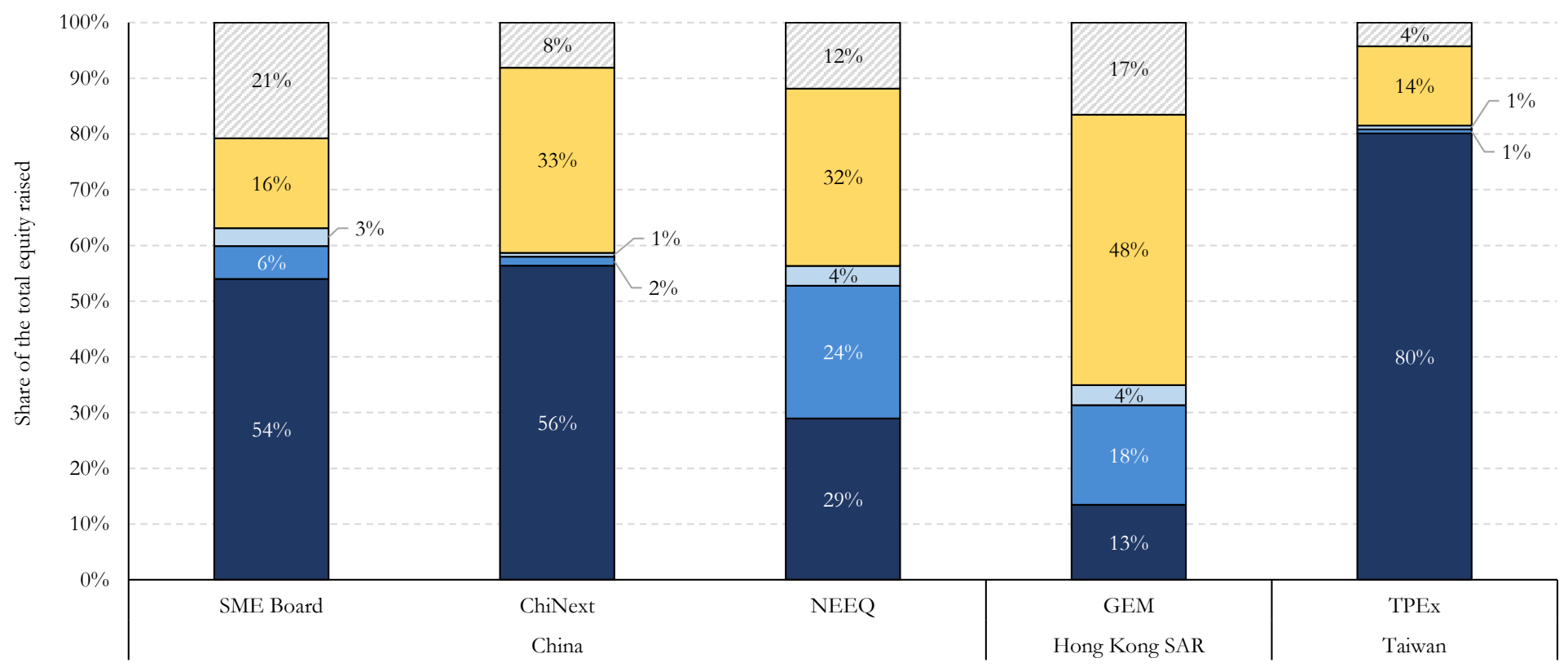

$\square$ Manufacturing $\square$ Finance, insurance, and real estate $\quad \square$ Transportation and utilities $\square$ Other services $\quad \square$ Other sectors 


\section{Appendix Table 1. Economy Classification}

This table shows the list of economies that are included in the different regions.

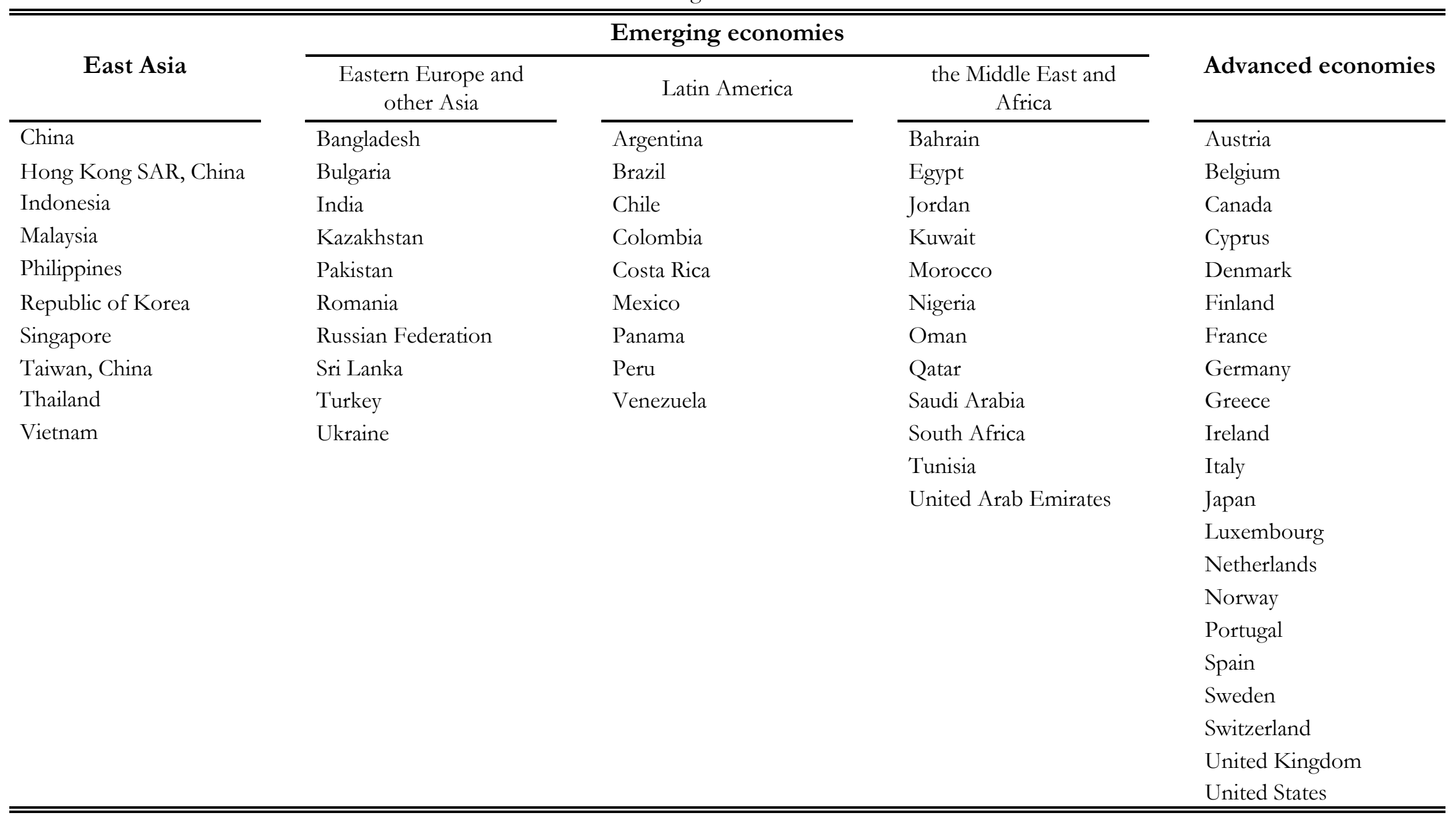




\section{Appendix Table 2. Share Raised in Domestic Markets}

This table shows OLS regressions of the share of the total amount raised in domestic markets per East Asian firm and year during 1990-2016 on two period dummies (1998-2007 and 2008-16). The regressions include firm fixed effects (FE). Standard errors are reported in brackets and are clustered at the economy-industry level. *, **, and *** denote statistical significance at $10 \%, 5 \%$, and $1 \%$, respectively.

\begin{tabular}{|c|c|c|}
\hline \multirow{2}{*}{$\frac{\text { Dependent variable: }}{\text { Type of instrument: }}$} & \multicolumn{2}{|c|}{$\begin{array}{l}\text { Share of the total raised in } \\
\text { domestic markets per firm and year }\end{array}$} \\
\hline & Equity & Corporate bonds \\
\hline Period 1999-07 & $0.02 * *$ & $0.11 * *$ \\
\hline Period 2008-16 & $\begin{array}{l}\lceil 0.01\rceil \\
0.02 * * \\
\lceil 0.01\rceil\end{array}$ & $\begin{array}{l}\lceil 0.05\rceil \\
0.17 * * * \\
\lceil 0.06\rceil\end{array}$ \\
\hline Firm FE & Yes & Yes \\
\hline $\begin{array}{l}\text { No. of observations } \\
\text { No. of clusters } \\
\text { R-squared } \\
\end{array}$ & $\begin{array}{r}22,594 \\
87 \\
0.87 \\
\end{array}$ & $\begin{array}{r}21,827 \\
80 \\
0.69 \\
\end{array}$ \\
\hline
\end{tabular}




\section{Appendix Table 3. Size (Assets) of Equity and Corporate Bond Issuers}

This table shows OLS regressions of the size of East Asian equity and corporate bond issuers during 1990-2016 on two period dummies (1999-07 and 2008-16). The dependent variable is the median issuer size (in logs) per economy, industry, and period. Firm size is measured as the average assets size of firms at issuance over the whole sample period, 1990-2016. The firm size variable is winsorized at the $5 \%$ level to remove outliers, as the difference in size across firms in terms of assets is very large. The regressions include economy-industry fixed effects (FE). Standard errors are reported in brackets and are clustered at the economyindustry level. *,**, and $* * *$ denote statistical significance at $10 \%, 5 \%$, and $1 \%$, respectively.

\begin{tabular}{|c|c|c|c|c|c|c|}
\hline \multirow{2}{*}{$\begin{array}{c}\text { Type of instrument: } \\
\text { Base period: 1990-98 }\end{array}$} & \multicolumn{3}{|c|}{ Equity } & \multicolumn{3}{|c|}{ Corporate bonds } \\
\hline & Total & Domestic & International & Total & Domestic & International \\
\hline Period 1999-07 & $\begin{array}{l}-0.64^{* * *} \\
{[0.12]}\end{array}$ & $\begin{array}{l}-0.51 * * * \\
{[0.11]}\end{array}$ & $\begin{array}{l}-0.71 * * * \\
{[0.24]}\end{array}$ & $\begin{array}{l}-0.27 * * \\
{[0.11]}\end{array}$ & $\begin{array}{l}-0.24 * \\
{[0.13]}\end{array}$ & $\begin{array}{r}0.01 \\
{[0.13]}\end{array}$ \\
\hline Period 2008-16 & $\begin{array}{l}-0.93 * * * \\
{[0.13]}\end{array}$ & $\begin{array}{l}-0.80 * * * \\
{[0.13]}\end{array}$ & $\begin{array}{l}-0.87 * * * \\
{[0.28]}\end{array}$ & $\begin{array}{l}-0.50 * * * \\
{[0.14]}\end{array}$ & $\begin{array}{l}-0.33^{* *} \\
{[0.14]}\end{array}$ & $\begin{array}{r}0.04 \\
{[0.14]}\end{array}$ \\
\hline Economy-industry FE & Yes & Yes & Yes & Yes & Yes & Yes \\
\hline No. of observations & 250 & 249 & 161 & 233 & 219 & 192 \\
\hline No. of clusters & 87 & 87 & 64 & 82 & 80 & 72 \\
\hline R-squared & 0.79 & 0.76 & 0.82 & 0.81 & 0.79 & 0.86 \\
\hline
\end{tabular}




\section{Appendix Table 4. Capital Market Reforms - Indonesia}

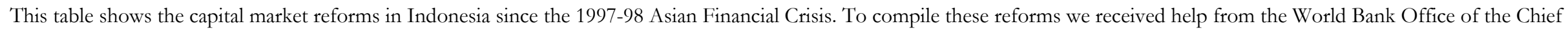
Economist for East Asia and Pacific and financial sector experts in the region.

\begin{tabular}{|c|c|c|c|c|}
\hline \multirow[b]{2}{*}{ Year } & \multicolumn{3}{|c|}{ Type of policy } & \multirow[b]{2}{*}{ Policy description } \\
\hline & $\begin{array}{l}\text { Expansion of } \\
\text { investor base }\end{array}$ & $\begin{array}{c}\text { Improvement of } \\
\text { market } \\
\text { infrastructure }\end{array}$ & $\begin{array}{c}\text { Enhancement of } \\
\text { investor } \\
\text { protection }\end{array}$ & \\
\hline 1997 & $\checkmark$ & & & Revocation of stock purchase limit by foreign investors \\
\hline 1997 & & $\checkmark$ & & Regulation of assets-backed securities \\
\hline 2006 & & & $\sqrt{ }$ & Regulation of existing sharia capital market \\
\hline 2007 & & $\sqrt{ }$ & & Merge of Jakarta Stock Exchange and Surabaya Stock Exchange \\
\hline 2008 & & & $\sqrt{ }$ & Establishment of Indonesia Bond Pricing Agency \\
\hline 2011 & & & $\sqrt{ }$ & Enactment of law on Financial Services Authority (OJK) \\
\hline 2012 & & & $\checkmark$ & Establishment of OJK \\
\hline 2013 & & $\checkmark$ & & Development of capital market data warehouse system \\
\hline 2013 & & $\checkmark$ & & Enactment of regulation to facilitate share buybacks under fluctuating market conditions \\
\hline 2013 & & $\checkmark$ & & Facilitatation of settlement of transactions using custodian banks \\
\hline 2013 & & & $\checkmark$ & Launch of investor protection fund \\
\hline 2013 & & & $\sqrt{ }$ & Establishment of single investor identity \\
\hline 2014 & & $\sqrt{ }$ & & Implementation of new lot sizes and price fractions \\
\hline 2014 & & & $\checkmark$ & Enactment of OJK regulation on sustainable public offering \\
\hline 2014 & & & $\sqrt{ }$ & Launch of roadmap to good corporate governance for issuers and public companies \\
\hline 2015 & $\checkmark$ & & & Regulation of exchange-traded funds \\
\hline 2015 & & & $\checkmark$ & New regulation of the sharia capital market \\
\hline 2015 & & & $\checkmark$ & Launch of issuers reporting system through extensible business reporting language \\
\hline 2016 & & $\checkmark$ & & Launch of electronic licensing and registration system \\
\hline 2016 & & $\checkmark$ & & Launch of integrated investment management system \\
\hline 2016 & & $\checkmark$ & & Establishment of Indonesia securities financing \\
\hline 2016 & & & $\sqrt{ }$ & Launch of investor alert portal \\
\hline
\end{tabular}




\section{Appendix Table 5. Capital Market Reforms - Korea}

This table shows the capital market reforms in Korea since the 1997-98 Asian Financial Crisis. To compile these reforms we received help from the World Bank Office of the Chief Economist for East Asia and Pacific and financial sector experts in the region.

\begin{tabular}{|c|c|c|c|c|}
\hline \multirow[b]{2}{*}{ Year } & \multicolumn{3}{|c|}{ Type of policy } & \multirow[b]{2}{*}{ Policy description } \\
\hline & $\begin{array}{l}\text { Expansion of } \\
\text { investor base }\end{array}$ & $\begin{array}{c}\text { Improvement of } \\
\text { market } \\
\text { infrastructure }\end{array}$ & $\begin{array}{c}\text { Enhancement of } \\
\text { investor } \\
\text { protection }\end{array}$ & \\
\hline 1998 & $\checkmark$ & & & Elimination of restrictions on investments by foreign investors \\
\hline 1998 & $\checkmark$ & & & Introduction of mutual funds \\
\hline 1998 & & $\checkmark$ & & Introduction of asset-backed securities \\
\hline 1998 & & & $\checkmark$ & Enhancement of corporate governance practices \\
\hline 1999 & & $\checkmark$ & & Introduction of mark-to-market system \\
\hline 2000 & & $\checkmark$ & & Approval of inter-dealer brokers to act as intermediares \\
\hline 2004 & & & $\checkmark$ & Enactment of Indirect Investment Asset Management Business Act \\
\hline 2005 & $\sqrt{ }$ & & & Introduction of retirement pension system \\
\hline 2005 & & $\checkmark$ & & Launch of Korea Exchange (KRX) \\
\hline 2007 & & & $\checkmark$ & Enactment of Financial Investment Services and Capital Markets Act \\
\hline 2012 & $\checkmark$ & & & Launch of Korean hedge funds \\
\hline 2012 & & $\checkmark$ & & Removal of limit on corporate bond issuances amounts \\
\hline 2015 & $\checkmark$ & & & $\begin{array}{l}\text { Adoption of individual savings account (ISA), allowing individuals to invest in } \\
\text { various financial products through a single account }\end{array}$ \\
\hline
\end{tabular}




\section{Appendix Table 6. Capital Market Reforms - Malaysia}

This table shows the capital market reforms in Malaysia since the 1997-98 Asian Financial Crisis. To compile these reforms we received help from the World Bank Office of the Chief Economist for East Asia and Pacific and financial sector experts in the region.

\begin{tabular}{|c|c|c|c|c|}
\hline \multirow[b]{2}{*}{ Year } & \multicolumn{3}{|c|}{ Type of policy } & \multirow[b]{2}{*}{ Policy description } \\
\hline & $\begin{array}{l}\text { Expansion of } \\
\text { investor base }\end{array}$ & $\begin{array}{c}\text { Improvement of } \\
\text { market } \\
\text { infrastructure }\end{array}$ & $\begin{array}{c}\text { Enhancement of } \\
\text { investor } \\
\text { protection }\end{array}$ & \\
\hline 2000 & & & $\checkmark$ & Release of Malaysian code on corporate governance \\
\hline 2003 & & $\checkmark$ & & Streamline of IPO approval process \\
\hline 2003 & & $\checkmark$ & & Standarization of lot sizes \\
\hline 2003 & & $\checkmark$ & & Demutualistion of Kuala Lumpur Stock Exchange (KLSE) \\
\hline 2004 & & $\checkmark$ & & Enactment of revised guidelines on the offering of private debt securities \\
\hline 2004 & & $\checkmark$ & & Immediate approval of bond issues for selected issuers \\
\hline 2004 & & & $\checkmark$ & Enhancement of corporate disclosure \\
\hline 2006 & & $\checkmark$ & & Facilitatation of foreign-owned firms listings on domestic markets \\
\hline 2007 & & & $\checkmark$ & Enhancement of corporate governance provisions \\
\hline 2007 & & & $\checkmark$ & Enactment of Capital Markets and Services Act 2007 \\
\hline 2008 & & $\checkmark$ & & Introduction of greenshoe mechanism \\
\hline 2009 & & $\checkmark$ & & Reduction of cost of regulatory compliance \\
\hline 2009 & & $\checkmark$ & & Establishment of credit guarantees for lower-rated firms issuing bonds \\
\hline 2009 & & $\checkmark$ & & Comprehensive revamp of Malaysia exchange structure \\
\hline 2012 & $\checkmark$ & & & Introduction of retail investors to corporate bond market \\
\hline
\end{tabular}




\section{Appendix Table 7. Capital Market Reforms - Philippines}

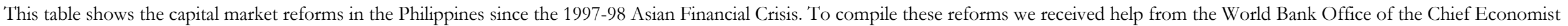
for East Asia and Pacific and financial sector experts in the region.

\begin{tabular}{|c|c|c|c|c|}
\hline \multirow[b]{2}{*}{ Year } & \multicolumn{3}{|c|}{ Type of policy } & \multirow[b]{2}{*}{ Policy description } \\
\hline & $\begin{array}{l}\text { Expansion of } \\
\text { investor base }\end{array}$ & $\begin{array}{c}\text { Improvement of } \\
\text { market } \\
\text { infrastructure }\end{array}$ & $\begin{array}{c}\text { Enhancement of } \\
\text { investor } \\
\text { protection }\end{array}$ & \\
\hline 1998 & & & $\sqrt{ }$ & Provision of self-regulatory organization status to the Philippine Stock Exchange (PSE) \\
\hline 2000 & & & $\sqrt{ }$ & Enactment of securities regulation code \\
\hline 2002 & & & $\sqrt{ }$ & Issuance of circulars promulgating the code of corporate governance \\
\hline 2004 & & & $\sqrt{ }$ & Obligation of compliance with international financial reporting standards (IFRS) \\
\hline 2006 & & $\sqrt{ }$ & & Introduction of bond exchange/swaps \\
\hline 2007 & & $\sqrt{ }$ & & Introduction of corporate securities in Philippine Dealing and Exchange (PDeX) trading board \\
\hline 2008 & $\sqrt{ }$ & & & Enactment of Personal Equity and Retirement Account (PERA) Law \\
\hline 2008 & & $\sqrt{ }$ & & Authorization of corporate bond trading for public through accredited brokers on PDeX \\
\hline 2008 & & $\sqrt{ }$ & & Removal of documentary stamp taxes on securities trading \\
\hline 2010 & & $\checkmark$ & & Enactment of regulation requiring listed companies to maintain a ten percent public float \\
\hline 2013 & $\checkmark$ & & & Enactment of rules and regulations on exchange-traded funds \\
\hline 2015 & & & $\sqrt{ }$ & Implementation of rules and regulations of the securities regulation code \\
\hline 2016 & & $\sqrt{ }$ & & Approval of public-private partnership (PPP) listing rules \\
\hline 2016 & & & $\sqrt{ }$ & Launch of corporate governance code for publicly listed companies \\
\hline
\end{tabular}




\section{Appendix Table 8. Capital Market Reforms - Vietnam}

This table shows the capital market reforms in Vietnam since the 1997-98 Asian Financial Crisis. To compile these reforms we received help from the World Bank Office of the Chief Economist for East Asia and Pacific and financial sector experts in the region.

\begin{tabular}{|c|c|c|c|c|}
\hline \multirow[b]{2}{*}{ Year } & \multicolumn{3}{|c|}{ Type of policy } & \multirow[b]{2}{*}{ Policy description } \\
\hline & $\begin{array}{l}\text { Expansion of } \\
\text { investor base }\end{array}$ & $\begin{array}{c}\text { Improvement of } \\
\text { market } \\
\text { infrastructure }\end{array}$ & $\begin{array}{c}\text { Enhancement of } \\
\text { investor } \\
\text { protection }\end{array}$ & \\
\hline 2000 & & $\checkmark$ & & Launch of Ho Chi Minh City Stock Exchange (HOSE) \\
\hline 2005 & & $\checkmark$ & & Launch of Hanoi Stock Exchange (HNX) \\
\hline 2006 & & $\checkmark$ & & Authorization of domestic bond issuances for companies \\
\hline 2007 & & & $\checkmark$ & Enactment of Securities Law \\
\hline
\end{tabular}




\section{Appendix Table 9. Traditional vs. SME Capital Markets}

This table shows indicators on equity issuers in traditional and SME capital markets in China, Hong Kong SAR, and Taiwan. Assets and the number of employees of issuing firms correspond to the median equity issuer. Firm-level data are averages across all years per firm. Values for the traditional markets, SME Board, GEM, and TPEx are for the period 2004-16. Values for ChiNext are for the period 2009-16 and values for NEEQ are for the period 2013-16. Only data on IPO issuances are included for TPEx. Amount raised and asset values are reported in millions of constant 2011 U.S. dollars (USD).

\begin{tabular}{|c|c|c|c|c|}
\hline Market & $\begin{array}{c}\text { Number of } \\
\text { firms issuing } \\
\text { per year }\end{array}$ & $\begin{array}{c}\text { Amount raised } \\
\text { per year } \\
\text { (million USD) }\end{array}$ & $\begin{array}{c}\text { Assets of } \\
\text { issuing firms } \\
\text { (million USD) }\end{array}$ & $\begin{array}{l}\text { Number of } \\
\text { employees of } \\
\text { issuing firms }\end{array}$ \\
\hline \multicolumn{5}{|l|}{ Traditional markets } \\
\hline China & 317 & 72,095 & 214 & 1,359 \\
\hline Hong Kong SAR & 362 & 61,763 & 116 & 643 \\
\hline Taiwan & 158 & 5,945 & 68 & 448 \\
\hline \multicolumn{5}{|l|}{ SME markets } \\
\hline SME Board (China) & 124 & 18,355 & 238 & 1,502 \\
\hline ChiNext (China) & 116 & 12,070 & 124 & 673 \\
\hline NEEQ (China) & 1,217 & 10,169 & 13 & 135 \\
\hline GEM (Hong Kong SAR) & 101 & 1,094 & 25 & 104 \\
\hline TPEx (Taiwan) & 395 & 655 & 40 & $\mathrm{n} / \mathrm{a}$ \\
\hline
\end{tabular}

